\title{
Wage elasticities of the supply of knowledge workers in the Netherlands
}

Citation for published version (APA):

Maray, P., \& Borghans, L. (2000). Wage elasticities of the supply of knowledge workers in the Netherlands. Researchcentrum voor Onderwijs en Arbeidsmarkt, Faculteit der Economische Wetenschappen. ROA Reports No. 6E https://doi.org/10.26481/umarep.200006E

Document status and date:

Published: 01/01/2000

DOI:

10.26481/umarep.200006E

Document Version:

Publisher's PDF, also known as Version of record

\section{Please check the document version of this publication:}

- A submitted manuscript is the version of the article upon submission and before peer-review. There can be important differences between the submitted version and the official published version of record.

People interested in the research are advised to contact the author for the final version of the publication, or visit the DOI to the publisher's website.

- The final author version and the galley proof are versions of the publication after peer review.

- The final published version features the final layout of the paper including the volume, issue and page numbers.

Link to publication

\footnotetext{
General rights rights.

- You may freely distribute the URL identifying the publication in the public portal. please follow below link for the End User Agreement:

www.umlib.nl/taverne-license

Take down policy

If you believe that this document breaches copyright please contact us at:

repository@maastrichtuniversity.nl

providing details and we will investigate your claim.
}

Copyright and moral rights for the publications made accessible in the public portal are retained by the authors and/or other copyright owners and it is a condition of accessing publications that users recognise and abide by the legal requirements associated with these

- Users may download and print one copy of any publication from the public portal for the purpose of private study or research.

- You may not further distribute the material or use it for any profit-making activity or commercial gain

If the publication is distributed under the terms of Article $25 \mathrm{fa}$ of the Dutch Copyright Act, indicated by the "Taverne" license above, 


\title{
Wage Elasticities of the Supply of Knowledge Workers in the Netherlands
}

\author{
ROA-R-2000/6E
}

Philip Marey

Lex Borghans

Research Centre for Education and the Labour Market

Faculty of Economics and Business Administration

Maastricht University

Maastricht, May 2000 
ISBN 90-5321-283-3

Sec00.085/PM 


\section{Contents}

pages

Voorwoord (Dutch preface) i

Samenvatting (Dutch summary) iii

Summary vii

1 Introduction 1

2 The wage elasticity of supply 5

2.1 R\&D expenditure, wages and activities 5

$\begin{array}{ll}2.2 \text { Knowledge activities and the components of supply } & 7\end{array}$

3 Econometric pitfalls $\quad 11$

$\begin{array}{lr}4 \text { A simple analytical model } & 19\end{array}$

5 Evidence from the US 23

6 Evidence from Dutch cross-sectional micro-data 31

6.1 The wages of university-level engineers $\quad 32$

6.2 The wage elasticities of the supply of university-level engineers 33

7 Evidence from Dutch macro time series $\quad 37$

$\begin{array}{ll}\text { Appendix 7.A } & 53\end{array}$

8 Evidence from European macro time series $\quad 55$

9 Conclusion 63

$\begin{array}{ll}\text { References } & 67\end{array}$ 


\section{Voorwoord (Dutch preface)}

Dit rapport bevat de resultaten van het project "De loonelasticiteiten van het aanbod van kenniswerkers in Nederland", dat het Researchcentrum voor Onderwijs en Arbeidsmarkt (ROA) van de Universiteit Maastricht heeft uitgevoerd in opdracht van het Directoraat Algemene Economische Politiek van het Ministerie van Economische Zaken.

Aanleiding voor dit onderzoek is dat in de economische literatuur de laatste jaren veel aandacht uitgaat naar het economische belang om Research \& Development (R\&D) te stimuleren, vanwege de positieve externe effecten. Het effect van dergelijke stimulerende investeringen kan echter ernstig beperkt worden als het aanbod van kenniswerkers inelastisch is: dat wil zeggen als een extra investering in R\&D met name leidt tot een strijd tussen R\&D-bedrijven om de beschikbare onderzoekers en daarmee tot hogere lonen voor de bestaande groep kenniswerkers en nauwelijks leidt tot de instroom van nieuwe kenniswerkers. Het stimuleringsbeleid van de overheid zou daardoor niet alleen haar eigen $R \& D$, maar ook de R\&D van bedrijven duurder maken.

Voor de Verenigde Staten zijn er inderdaad aanwijzingen dat een dergelijk crowding out effect plaatsvindt. Voor Europa in het algemeen of Nederland in het bijzonder zijn dergelijke schattingen niet beschikbaar.

Omdat het beleidsmatig van groot belang is, heeft dit onderzoek tot doel om ook voor Nederland inzicht te krijgen in de loonelasticiteiten van kenniswerkers. Een dergelijke analyse is echter om twee redenen niet zonder complicaties. Ten eerste beschikken we in Nederland niet over data die even gedetailleerd zijn als de cijfers die beschikbaar zijn voor de VS. Ten tweede is het betrouwbaar vaststellen van loonelasticiteiten, econometrisch gezien een lastig probleem. De lonen worden immers bepaald door een interactie van vraag en aanbod. Om de effecten van overheidsbeleid op de loonontwikkeling vast te stellen moet het effect van een veranderende vraag gescheiden worden van aanbodeffecten. De aanpak die wij daarom gekozen hebben is om de mogelijke schattingstechnieken grondig te analyseren en hun voor- en nadelen expliciet te bespreken, gebruik te maken van verschillende databronnen en ook cijfers te gebruiken van andere Europese landen en de VS. Op deze wijze proberen we zicht te krijgen op de gevoeligheid van de resultaten voor verschillende databronnen en verschillende schattingsmethoden, zodat een goed beeld ontstaat van de robuustheid van de resultaten.

De onderzoekers danken de leden van de begeleidingscommissie, Eric Bartelsman, Foppe de Haan, Jeroen Hinloopen, Trea Laske-Aldershof, Dick Polman, Theo Roelandt en Richard Venniker voor hun inbreng bij de totstandkoming van het rapport. Verder danken wij Walther Goorden van het KIvl voor het beschikbaar stellen van de KIvl Salarisenquête 1998 en Austan Goolsbee voor het beschikbaar stellen van de Amerikaanse data die hij in zijn onderzoek gebruikt heeft. 


\section{Samenvatting (Dutch summary)}

$R \& D$ is van groot belang voor economische groei. Vanwege de externe effecten van kennis, bestaat het gevaar dat ondernemingen minder kennisactiviteiten verrichten dan optimaal is voor de economie als geheel. Hier lijkt dan ook een rol voor de overheid weggelegd om R\&D-uitgaven te stimuleren. De vraag is echter of deze extra R\&D-uitgaven daadwerkelijk leiden tot extra kennisactiviteiten. Het aanbod van kenniswerkers is namelijk beperkt, met name op de korte termijn aangezien het opleiden van kenniswerkers vele jaren vergt. De empirische resultaten in dit rapport tonen aan dat van elke extra R\&D-gulden bijna 30 cent verdwijnt als loonsverhogingen voor reeds aanwezige kenniswerkers.

Een belangrijk inzicht uit de endogene groeitheorie is dat R\&D van cruciaal belang is voor economische groei. Spillovers van kennis kunnen er echter toe leiden dat het rendement van $R \& D$ voor de individuele onderneming lager is dan het rendement voor de economie als geheel. Het gevolg is dat bedrijven minder R\&D ondernemen dan optimaal is vanuit een macro-perspectief: het groeipotentieel van de economie wordt niet volledig benut. Overheidsingrijpen door middel van subsidies, R\&D door quasi-publieke instellingen en overheidsinvesteringen in kennisinfrastructuur kunnen hierin een ondersteunende rol spelen.

Het probleem van deze vorm van interventie is echter dat er slechts een beperkt aantal mensen is dat in staat is om de extra onderzoeksprojecten op adequate wijze uit te voeren. Kenniswerkers belichamen namelijk een grote hoeveelheid menselijk kapitaal, die aanleg en vele jaren scholing vereist. Het aanbod van kenniswerkers is daarom mogelijk niet erg elastisch. Met name op de korte termijn kan dit een beperkende factor voor het beleid betekenen. De lage loonelasticiteiten van het aanbod van kenniswerkers bepalen de grenzen aan publieke interventie in R\&D. Als het aanbod van kenniswerkers relatief inelastisch is op de korte termijn, zal een toename van de R\&D-uitgaven een opwaarts effect hebben op de lonen van kenniswerkers, omdat werkgevers in hevige concurrentie zijn om een kleine groep kenniswerkers. Overheidsmaatregelen om R\&D te stimuleren zullen daarom leiden tot hogere lonen, zowel in de publieke als de particuliere sector. In de hele economie worden kennisactiviteiten duurder, terwijl de omvang van de kennisactiviteiten weinig toeneemt.

Recent onderzoek in de Verenigde Staten toont aan dat het aanbod van kenniswerkers daar inderdaad weinig elastisch is. Het gevolg is dat een toename in federale R\&D-uitgaven van $1.0 \%$ leidt tot een inkomenstoename voor kenniswerkers van $0.2 \%$, hetgeen betekent dat slechts een deel van de extra R\&D-uitgaven besteed wordt aan extra kennisactiviteiten. Voor Nederland en andere Europese landen waren dergelijke schattingen niet beschikbaar. Vanuit een beleidsperspectief is het daarom van belang om inzicht te krijgen in de effecten van additionele R\&Duitgaven op de lonen en het aanbod van kenniswerkers in Nederland. In dit rapport wordt daarbij in het bijzonder aandacht geschonken aan de dynamiek op de arbeids- 
markt voor kenniswerkers. De econometrische analyse is zodanig opgezet dat we korte-termijn-effecten van lange-termijn-effecten kunnen onderscheiden en daarnaast de uitkomsten op de arbeidsmarkt voor kenniswerkers kunnen opsplitsen in aanbod-effecten en vraag-effecten.

Figuur 1

Schematisch overzicht van de werking van de arbeidsmarkt voor kenniswerkers in Nederland

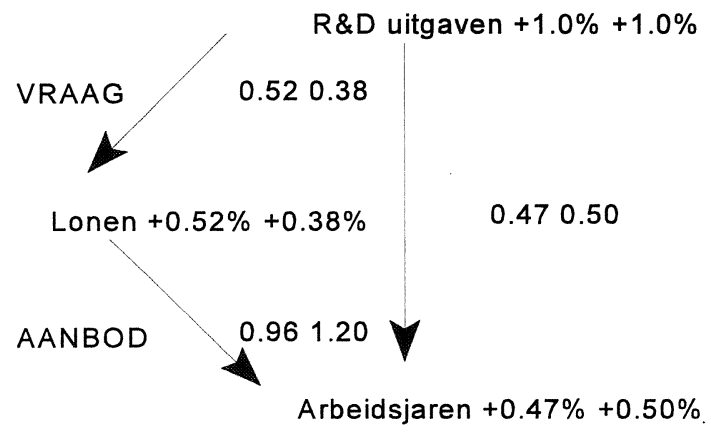

De meest waardevolle bron van informatie met betrekking tot kenniswerkers in Nederland is de R\&D-Enquête van het CBS. Op basis van een econometrische analyse van tijdreeksen van R\&D-uitgaven, lonen en arbeidsjaren van kenniswerkers kan de werking van de Nederlandse arbeidsmarkt voor kenniswerkers als volgt beschreven worden (zie ook figuur 1). Op de korte termijn heeft een toename in R\&D-uitgaven een sterk opwaarts effect op lonen, terwijl het aanbod van kenniswerkers nog niet zijn maximale gevoeligheid voor loonprikkels heeft bereikt: de korte-termijn-loonelasticiteit van het aanbod van kenniswerkers is 0,96 . Een stijging van de R\&D-uitgaven met $1 \%$ leidt op de korte termijn tot $0,47 \%$ toename in kennisactiviteiten en een loonstijging van $0,52 \%$. Op de lange termijn, als de R\&Duitgaven op het verhoogde niveau gehandhaafd blijven, wordt de reactie van het aanbod groter. Het effect van de R\&D-uitgaven op de lonen neemt af, terwijl de gevoeligheid van het aanbod van kenniswerkers voor de hogere lonen verder toeneemt: de lange-termijn-loonelasticiteit van het aanbod van kenniswerkers is 1,20 . Een stijging van de R\&D-uitgaven met $1 \%$ leidt op de lange termijn tot $0,50 \%$ 
toename in kennisactiviteiten en een loonstijging van $0,38 \%$. Het netto-resultaat van deze dynamische vraag- en aanbodinteractie is dat het korte-termijn-effect op de kennisactiviteiten $(0,47 \%)$ ongeveer gelijk is aan het lange-termijn-effect $(0,50 \%)$. Met andere woorden, bij een toename in R\&D-uitgaven wordt in eerste instantie de lage korte-termijn-elasticiteit van het aanbod van kenniswerkers gecompenseerd door middel van forse loonsverhogingen. Op de lange termijn is de aanbodzijde elastischer en neemt het opwaartse effect van R\&D-uitgaven op lonen weer enigszins af. Tegelijkertijd nemen de uitgaven aan materiaal en gebouwen echter verder toe. Per saldo stijgt de R\&D-activiteit nog maar in beperkte mate.

Een rekensom met deze geschatte elasticiteiten leert dat op de korte termijn van elke extra R\&D-gulden 26 cent gebruikt wordt voor extra kennisactiviteiten, 45 cent wordt besteed aan extra apparatuur en gebouwen, terwijl 29 cent verdwijnt als extra loon voor de reeds beschikbare kenniswerkers. Van de extra loonkosten gaat dus $53 \%$ naar hogere lonen en $47 \%$ naar meer mensen. Op de lange termijn lekt er nog steeds 21 cent weg in de vorm van hogere lonen, terwijl er niet veel meer aan extra kennisactiviteiten wordt besteed, namelijk 28 cent. De overige 51 cent wordt besteed aan nieuwe apparatuur en gebouwen. Na verloop van tijd gaat dus nog altijd $43 \%$ van de extra loonkosten naar hogere lonen en $57 \%$ naar meer mensen.

De elasticiteiten verschillen overigens per sector van de Nederlandse economie. Een permanente $1 \%$ toename in R\&D-uitgaven leidt tot een toename in kennisactiviteiten van $1,0 \%$ bij universiteiten, waarbij de aanbodkant met name op lange termijn relatief elastisch is. Aan de andere kant van het spectrum heeft een permanente $1 \%$ toename in R\&D-uitgaven in de metaalindustrie slechts een $0,3 \%$ toename in kennisactiviteiten tot gevolg, vooral veroorzaakt door de vraagzijde.

Aanvullende cijfers van Eurostat geven aan dat de toename in kennisactiviteiten in Nederland vooral plaatsvindt binnen de hoogopgeleide kerngroep van kenniswerkers en in mindere mate door ondersteunende technici. Vergeleken met andere landen van de Europese Unie is het korte-termijn-effect van R\&D-uitgaven op de kennisactiviteiten van deze kerngroep van gemiddelde omvang, terwijl het lange-termijneffect relatief groot is.

Schattingen op basis van de KIvl-Salarisenquête 1998 laten zien dat er op individueel niveau voor de reeds werkzame TU-ingenieurs in Nederland zelfs sprake is van een negatieve loonelasticiteit van het aanbod in termen van het aantal uren per jaar per medewerker. Weliswaar leiden hogere lonen tot een vergroting van het aanbod als percentage van de normale arbeidsduur, maar tegelijkertijd neemt het aantal verlofdagen zo sterk toe dat het netto aantal uren per jaar afneemt. Als gevolg zullen verhoogde R\&D-uitgaven niet tot extra gewerkte uren van de reeds werkzame TU-ingenieurs leiden en moet de uitbreiding dus volledig uit nieuw aanbod worden gehaald. 


\section{Summary}

Endogenous growth theory shows the crucial importance of R\&D for economic growth. However, the effectiveness of R\&D policies is limited by the low wage elasticities of the supply of R\&D workers. Estimating these elasticities for the Netherlands is hampered by the lack of appropriate micro-data. The empirical literature suggests that estimating wage elasticities from macro-data may be impossible. However, we show that the identification problem can be solved by performing the instrumental variables approach in a cointegration framework. We apply this estimation approach to macro-data from the R\&D Survey of Statistics Netherlands. The wage elasticity of the supply of R\&D workers in the Netherlands is 0.96 in the short run and 1.20 in the long run. When R\&D expenditure is increased, the demand side of the labour market for R\&D workers compensates for the shortrun inflexibility of the supply side by strong wage increases in the short run and weaker responses in the long run. As a result, a 1.0\% increase in real R\&D spending will lead to a $0.5 \%$ increase in the employment of R\&D workers, both in the short run and in the long run. 


\section{Introduction}

An important insight from endogenous growth theory is that R\&D is of crucial importance for economic growth (Romer, 1986,1990). However, knowledge spillovers could lead to a sub-optimal level of R\&D activities in the private sector. As a result, the full growth potential of the economy is not realized. The public sector may play a supporting role by means of subsidies, R\&D by quasi-public organizations and government investments in knowledge infrastructure. The problem with this type of public intervention is, however, that there might be an insufficient supply of people who possess the skills to perform the additional research projects adequately. A large accumulation of human capital is embodied in knowledge workers, which takes many years of education and training. As a consequence, the supply of knowledge workers might be relatively inelastic in the short run. Since R\&D-activities require highly skilled specialists, it will take a long time for the educational system to adapt to a higher demand for such graduates.

The educational choices of new cohorts can only lead to considerable adjustments of the supply of knowledge workers in the long run. According to the human capital theory of Mincer (1958), Schultz (1961) and Becker (1962), the willingness of individuals to invest in their own human capital depends on the expected additional flow of future income which results from this investment. The choice of education is only the first step towards a career as a knowledge worker. The next steps take place after graduation and during the career. In the Netherlands about half of all technically educated end up in a non-technical occupation: in 1995 this was the case for $46 \%$ of graduates from higher vocational technical education and for $54 \%$ of technical university graduates (Borghans et al., 1995). For R\&D occupations this percentage is even higher. This is caused on the one hand because of the technologization of non-technical occupations - i.e. in more and more non-technical occupations, technical skills become valuable due to the introduction of computers and other technology - and the fact that technical professionals continue their career in managerial jobs, and on the other hand because technical occupations are often sensitive to the business cycle and thus non-technical occupations offer good employment opportunities during bad times (Borghans et al., 1997). However, there is some evidence that technically educated workers in non-technical occupations do not easily return to R\&D occupations at the moment demand increases in the R\&D sector. This may be caused by selection based on R\&D talent and skills obsolescence, which especially occurs in these technical jobs. Additional demand for R\&D could therefore lead to a loss of quality. It is therefore important to distinguish between technically educated and the subset that we could properly call knowledge workers. If it is difficult to substitute R\&D workers by other technically educated, the effect of additional $R \& D$ spending on $R \& D$ employment could be rather small.

Also in the long run - when the educational system has enough time to respond the demand for knowledge workers might be limited. If only a fraction of the pupils at 
school has enough talent for and interest in a career in research, the 'production of human capital' in this field will be limited. An increased lure for these research jobs might attract less talented pupils, lowering the productivity of this creative work. Although it does not seem to be very appropriate to qualify this a skills shortages, the 'natural endowments' of R\&D talents, might ultimately limit the possibilities for research.

The possibly low elasticities of supply determine the limits to public intervention in the R\&D market. If the supply of knowledge workers is relatively inelastic in the short run, increases in R\&D spending may have upward effects on wages of knowledge workers as employers compete for the limited pool of knowledge workers. Public investments in R\&D to stimulate research might therefore lead to crowding out of the private sector by the public sector via rising wages and to higher costs for both the public and the private sector. In this case the policy measures primarily lead to a wage rise for knowledge workers instead of an increase in knowledge activities. From a policy perspective it is therefore important to get insight in the reaction of the supply of knowledge workers and their wages to an increase in R\&D expenditure. Goolsbee (1998) estimates the short-term elasticity of the supply of scientists and engineers in the United States somewhere between 0.1 and 0.2 . As a result, a $1 \%$ increase in R\&D expenditure (as a fraction of GDP) leads to $0.30 \%$ increase in the income of scientists and engineers in the short run. The effect of federal R\&D expenditure on income is somewhat smaller $(0.23 \%)$, while the effect on hours is not significantly different from zero. In other words, additional federal R\&D expenditure increases the wages of scientists and engineers, but seems to have little effect on knowledge activities. Goolsbee also provides an estimate of the effects of federal $R \& D$ expenditure in the short run (within one year) and in the medium run (four years): a sustained $1 \%$ increase in federal R\&D expenditure leads to a $0.09 \%$ increase in the income of scientists and engineers in the short run and a $0.17 \%$ increase in the medium run.

For the Netherlands and other European countries such estimates were not available. The objective of this study is therefore to assess the effects of R\&D expenditure on wages and knowledge activities in the Netherlands, in order to get a grasp of the costs of and the limits to expanded research activities. The determination of the wage elasticity of the supply of knowledge workers in the Netherlands is however hampered by both the availability of data and by econometric problems. For the Netherlands there are no detailed micro-data as are available for the USA (as used by Goolsbee, 1998), so we have to rely on macrodata. The empirical literature suggests that the identification problem which occurs if we try to estimate wage elasticities from macro-data may be hard to solve (see for example Kimmel \& Kniesner, 1998). However, we will show that the econometric pitfalls can be solved by performing the instrumental variable approach in a cointegration framework. We will also provide estimates for other Member States of the European Union, as far as available harmonized data allow us, and compare the results with those for the Netherlands. In addition, we take a closer look at the robustness of the results which Goolsbee (1998) obtained for the United States. 
It is important to distinguish between short-term and long-term effects of R\&D expenditure on the labour market for knowledge workers. The dynamic causalities of R\&D expenditure, wages and knowledge activities can be very rich, as shown by David and Hall (1999), but we will focus on the effect of sectoral R\&D expenditure on the wages and knowledge activities of R\&D workers. ${ }^{1}$ In particular, we try to disentangle the demand side and supply side responses to increases in R\&D expenditure, both in the short run and in the long run. We will show that cointegration techniques are suited very well for these purposes.

The remainder of this report is organized as follows. In chapter 2 we focus on the causalities between R\&D expenditure, wages of knowledge workers and knowledge activities. Chapter 3 discusses the econometric pitfalls in the estimation of wage elasticities of supply and proposes an estimation approach which deals with these problems. Chapter 4 addresses the issues from a theoretical perspective by means of a rudimentary analytical model. In chapter 5 the empirical investigations start by a reconsideration of the evidence for the United States. In chapter 6 we turn to the Netherlands and investigate a cross-section of university-level engineers. Chapter 7 contains the key elasticities of this report, obtained from the R\&D Survey of Statistics Netherlands. Chapter 8 offers a comparison with other Member States of the European Union and chapter 9 concludes the report.

1. Throughout this report the terms "R\&D workers" and "knowledge workers" are interchangeable, as are "R\&D activities" and "knowledge activities". 


\section{The wage elasticity of supply}

\subsection{R\&D expenditure, wages and activities}

The three key variables of this study are R\&D expenditure, wages and activities, where activities will be measured in terms of employment, although measurement in terms of R\&D output would also be an option. At first sight, the most interesting causality is the direct effect of $R \& D$ expenditure on $R \& D$ activities. If we denote $R \& D$ expenditure by $x$ and R\&D employment by $n$ (both in natural logarithms), the relationship is expressed by the following equation.

$$
n=\theta+\beta x+\mu
$$

Since the variables are expressed in natural logarithms, the parameter $\beta$ can be interpreted as the $R \& D$ expenditure elasticity of $R \& D$ employment: a $1 \%$ increase in $R \& D$ expenditure will lead to a $\beta \%$ increase in $R \& D$ employment. From a policy perspective, this elasticity indicates the effectiveness of increased government R\&D spending on economy-wide knowledge activities. However, this elasticity gives no insight in the underlying mechanisms on the labour market for R\&D workers. For example, if a large portion of the additional R\&D expenditure is used for non-labour expenses - such as computers, machines, buildings etc. - then it is obvious that the effect on R\&D employment will be limited. In this case a low R\&D expenditure elasticity of R\&D employment is explained by factors on the demand side of the labour market for R\&D workers.

At the same time, there may also be supply side factors at work. The large stock of human capital which is embodied in R\&D workers takes considerable time to accumulate, hence the supply of R\&D workers may not be very elastic in the short run. The education of knowledge workers in universities takes a considerable amount of time. However, even if there is enough time to react to increased R\&D spending, possibilities for the educational market to react to increased demand might be limited. The decision to enrol in technical education will not only be determined by wages, but individual preferences and capabilities will also determine the choice for R\&D related courses at university. Furthermore, Borghans et al. (1995) have shown that large proportions of graduates from technical studies find employment outside the technical labour market domain. One of the reasons for this is that a fraction of the students discovers during their years at university that they lack the abilities or preferences to go into R\&D. Increased enrolment in these studies might increase this fraction of graduates who decide not to apply for an R\&D job.

As a result, the effectiveness of the portion of $R \& D$ expenditure which is used for labour expenses is limited by the wage elasticity of the supply of R\&D workers. From a policy point of view it is crucial to know on which side of the labour market the limited effectiveness of $R \& D$ expenditure originates. If wage elasticities of supply are 
low, then increased R\&D expenditure will only have a limited impact on knowledge creation. As far as the short run elasticities limit expansion, measures will have to be taken to increase the number of graduates which opt for a career in R\&D. Since the education and training of R\&D workers takes a lot of time, such a supply-side policy will take some time to get results. As far as the long run elasticity of supply restricts further expansion, the limits of R\&D policies are reached. The availability of people who are able to make a career in $R \& D$ and have the required abilities puts natural limits on the possibilities for endogenous growth.

In order to disentangle the demand side effects from the supply side effects and grasp the mechanisms on the labour market for $R \& D$ workers, the following two regression equations are relevant. The effect of $R \& D$ expenditure on wages can be captured by wage equation (2.2), where $w$ denotes the natural logarithm of wages.

$$
w=\theta_{w}+\beta_{w} x+\mu_{w}
$$

Due to the formulation in natural logarithms, the parameter $\beta_{w}$ can be interpreted as the $R \& D$ expenditure elasticity of wages. A $1 \%$ increase in $R \& D$ expenditure will lead to a $\beta_{w} \%$ increase in wages.

The labour supply equation (2.3) provides the effect of wages on labour supply.

$$
n=\theta_{n}+\beta_{n} w+\mu_{n}
$$

The parameter $\beta_{n}$ is the wage elasticity of the supply of $R \& D$ workers: if wages are increased by $1 \%$, then the supply of R\&D workers increases by $\beta_{n} \%$. In a model as described above wages are endogenous, which complicates estimation, as will be discussed later.

Estimation of equation (2.1) to (2.3) provides useful policy information about the effects of increases of R\&D expenditures by the government on both the wages and the number of R\&D workers available. The estimated parameters show how the market for R\&D workers is influenced by such a policy intervention. Estimation of the three equations is however far from straightforward. First, estimation is hampered by an identification problem, since supply and demand determine the wages simultaneously. Second, the market will require time to react to llarge policy intervention regarding R\&D expenditure. Therefore the parameters in (2.1) to (2.3) will affected by these time-lags. Notice also that equations (2.1)-(2.3) have been presented without subscripts referring to the sample. As a matter of fact, the equations are applicable both in the case of cross-section estimation and in the case of time series estimation. Assuming a steady state situation, cross-section estimates provide long run elasticities. In chapter 6 , a cross-section estimation is performed on a 1997 survey of Dutch university-level engineers. In chapter 7 and 8, time series 
estimations are applied. Depending on the way in which these time-series models are estimated either short and/or long run parameters will be found. For both applications there are further econometric pitfalls which are addressed in chapter 3.

By looking at all three elasticities obtained from equations (2.1)-(2.3), we are able to get a clear picture of the labour market for R\&D workers, as shown in figure 2.1. A $1 \%$ increase in R\&D expenditure will lead in a $\beta_{w} \%$ increase in wages. Given the fact that a $1 \%$ increase in wages leads to a $\beta_{n} \%$ increase in the supply of R\&D workers, the net effect of the $1 \%$ increase in R\&D expenditure is a $\beta \%$ increase in R\&D activities, as measured by R\&D employment. In other words, the three elasticities allow us to separate the demand side factors from the supply side factors which explain the effectiveness of R\&D expenditure in stimulating R\&D activities. In chapter 4 the relationship between these parameters will be discussed from a theoretical point of view.

Figure 2.1

R\&D expenditure, wages and employment

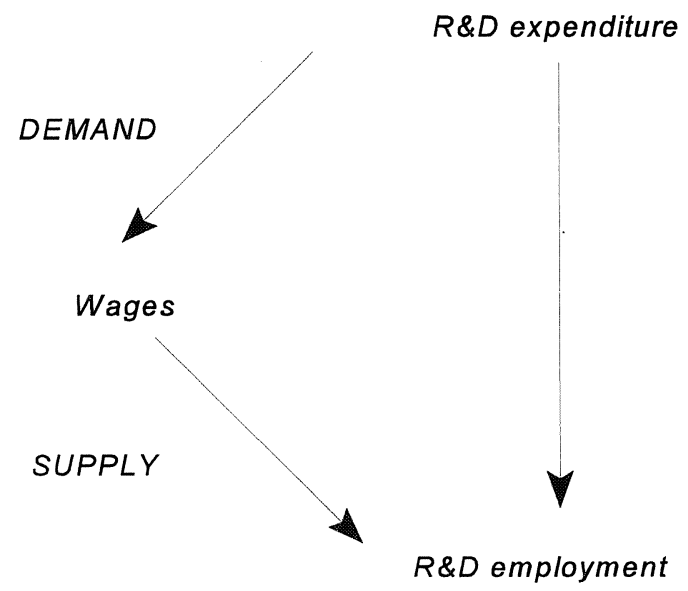

\subsection{Knowledge activities and the components of supply}

In order to perform empirical analyses, it is necessary to clarify what is exactly meant by "supply of knowledge workers" and "knowledge activities". As mentioned earlier, knowledge activities will be measured in terms of R\&D employment. This is essentially an input measure of activities. An output measure is for example the number of patents produced. However, since changes in the number of patents may also reflect changes in the way that firms internalize the results from R\&D, we will restrict the analyses in this study to input measures. It is important to note however that increased input might lead to a lower effectiveness per unit of input. Estimated 
expenditure elasticities might therefore even overestimate the effects of R\&D on research output.

As a starting point, notice that the total number of working hours by knowledge workers per year can be computed as the product of the following components:

- the number of knowledge workers;

- the size of the contract of the average knowledge worker (fraction of the full time equivalent);

- the number of working days per year of the full time contract.

The importance of this supply decomposition can be understood if we think in terms of labour contracts. In addition to the gross monthly wage, the typical employment contract in the Netherlands indicates both the working hours per week and the number of holidays and ADV-days. ${ }^{2}$ The terms of employment of a knowledge worker is therefore multi-dimensional, which has important consequences for a study on the supply of knowledge workers. To analyse the impact of R\&D expenditure on the level of knowledge activities, it is important to realize that knowledge workers might not only evaluate the level of the wage offers, but also the amount of holidays and ADV-days offered. The level of knowledge activities, expressed as the total number of working hours by knowledge workers per year, will be positively affected by higher wage offers, but at the same time an increase in the holidays and ADVdays offered will have an opposite effect. We can therefore distinguish between two effects of wages on labour supply: a positive substitution effect and a negative income effect. If the income effect is larger in size than the substitution effect, the supply curve is backward-bending.

The third channel through which knowledge activities can be increased is the number of knowledge workers. Better job offers in terms of higher wages and larger amounts of holidays and ADV-days are necessary conditions to attract more knowledge workers. However, they are not sufficient conditions if the supply of knowledge workers is inelastic. In this case, the availability of additional funds for $R \& D$ will primarily lead to an increase in the wages of the current stock of knowledge workers, and the level of knowledge activities only increases as far as the effort of the current knowledge workers rises.

As mentioned before, a related problem which may not be directly visible from the supply decomposition is that when the stock of knowledge workers increases as a result from better job offers, there may be a decrease in the average quality of knowledge workers, because of the possibly lower quality of the marginal knowledge workers. Knowledge activity measured as the total number of working hours per year

2. ADV-days (labour time reducation days) are days off resulting from collective bargaining aimed at reducing unemployment. 
is essentially a measure of input. A measure of output is, for example, the number of patents produced.

To summarize, an increase in R\&D spending may have some or all of the following effects:

- $\quad$ an increase in the weekly effort of average knowledge workers;

- $\quad$ an increase in the wage of the average knowledge worker;

- $\quad$ an increase in the holidays and ADV-days of knowledge workers;

- an increase in the number of knowledge workers;

- a decrease in the quality of the average knowledge worker.

The net effect on the level of knowledge activities, both in input terms (the number of working hours per year) and in output terms will probably be positive. However, there may be decreasing returns to R\&D expenditure, implying the existence of an optimum level of R\&D spending, above which the return to an additional R\&D guilder does not outweigh the cost. 


\section{Econometric pitfalls}

The empirical analysis of the interactions between R\&D expenditure, wages and activities focusses on three types of elasticities estimated from three equations. The supply side effects are captured by the wage elasticity of labour supply, which is estimated from the labour supply equation:

$$
n=\theta_{n}+\beta_{n} w+\mu_{n}
$$

The demand side effects are reflected by the R\&D expenditure elasticity of wages, which is estimated from the wage equation:

$$
w=\theta_{w}+\beta_{w} x+\mu_{w}
$$

The net effect of R\&D expenditure is measured by the R\&D expenditure elasticity of R\&D employment, estimated from:

$$
n=\theta+\beta x+\mu
$$

As mentioned earlier, estimation of these equations is far from straightforward. In this chapter we discuss three econometric pitfalls which hamper the estimation of these elasticities. The first issue is the identification problem which arises when we use data on wages and employment, since they are in fact the net results of the interaction between supply and demand. The second problem is the possible nonstationarity of macroeconomic variables and relates to the time lags that will affect the theoretical relationships. The third problem is the negative division bias which might follow from the computation of average working hours.

The identification problem is a long-standing issue in econometrics, which is caused by the fact that we do not directly observe demand and supply functions. The observed data on wages and employment may be in fact equilibrium outcomes of adjustment processes between labour supply and labour demand. In other words, we only observe the intersections of labour supply curves and labour demand curves, which makes it difficult separate the supply from the demand curve. It is important to note that (3.1) and (3.2) in fact represent a system of two equations which both relate the number of workers with wages, because R\&D expenditure is a function of the number of knowledge workers, their wages and additional research costs. Equation (3.1) and (3.2) therefore can be rewritten as a classical supply and demand curve. 
Figure 3.1

Identification of Supply Curves

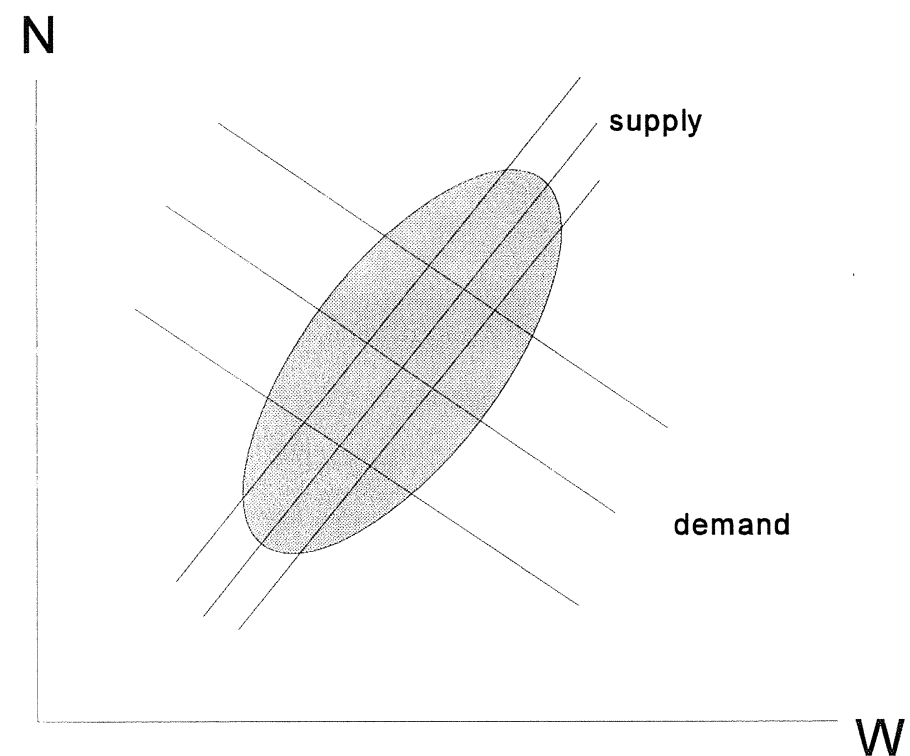

Figure 3.2

Identification of Demand Curves

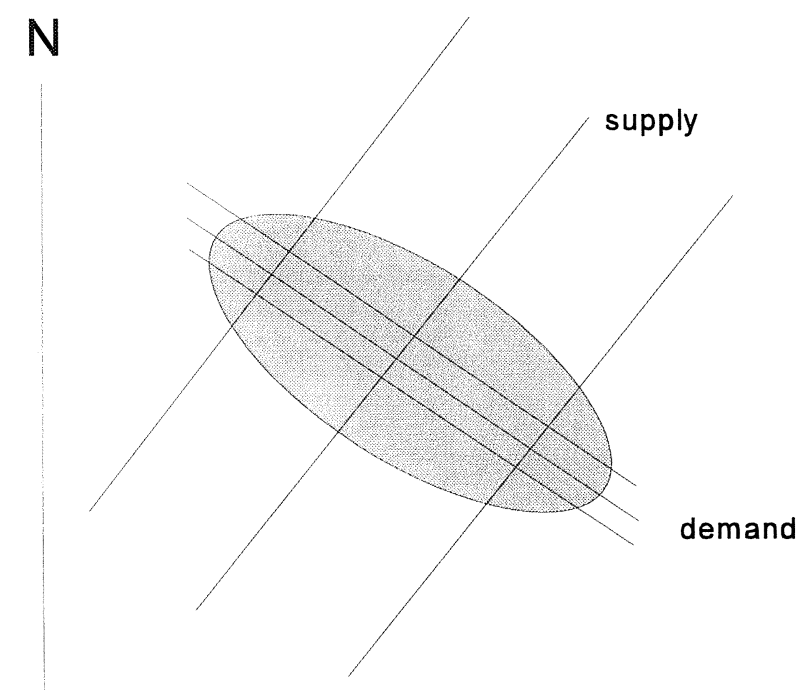


Figure 3.1 shows the circumstances under which it is possible to estimate a supply function and thus to get adequate wage elasticities of supply. If the shifts in the labour demand schedule are considerably larger than the shifts in the labour supply schedule, the intersections of the two curves will reveal the location of the labour supply schedule. When Moore (1914) tried to estimate the first demand curve, this was exactly what happened. Due to changes in demand and a rather stable supply curve, he estimated a positive sloping demand curve, therefore actually reflecting the supply curve.

If the opposite is the case, i.e. if the location of the labour supply curve has a higher variability than the labour demand curve, the intersections of the curves show the labour demand curve. This situation is depicted in figure 3.2, which thus shows the explanation of findings of negative wage elasticities of supply when aggregate data are used.

When there is no major difference in the variability of the labour demand and labour supply curves, it is impossible to detect either a supply curve or a demand curve, as shown in figure 3.3. Kniesner \& Goldsmith (1987) report that empirical studies based on macro data usually find negative or insignificant wage elasticitities.

Figure 3.3

No Identification of Supply/Demand Curves

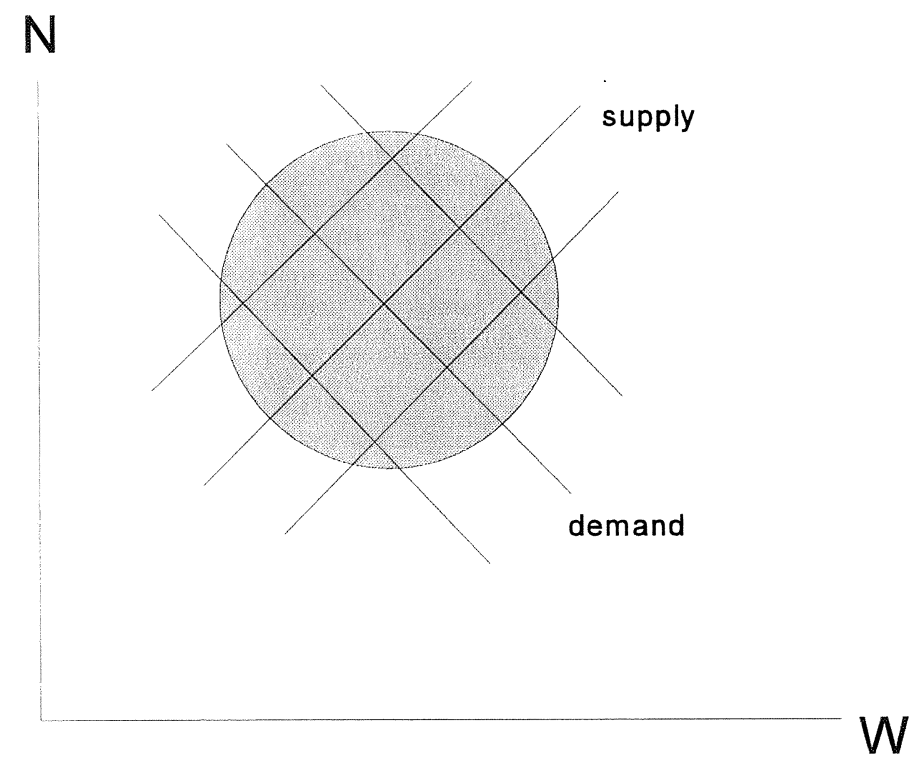

The core of the identification problem is that the wages which appear in labour supply equations such as (3.1) are clearly endogenous regressors. Hence one of the assumptions on which the usual test-statistics of the Ordinary Least Squares (OLS) 
method are based, i.e. the exogeneity of regressors, is violated. Demand effects on the wage rate cloud the relationship between wages and labour supply in the regression equation. The conventional remedy for problems of endogenous regressors is the Instrumental Variable (IV) method. The idea is to filter out the demand effects in the wage rate by performing an auxiliary regression which explains wages in terms of demand factors, see for example Kennan (1988) and Kimmel \& Kniesner (1998). Wage equation (3.2) suits this purpose very well: assuming $R \& D$ expenditure to be exogenous, this variable captures the demand influences on wages and may thus serve as an instrument. After estimating this auxiliary equation, the instrumental variable ("instrumented wages") is computed as the systematic part of regression equation (3.2).

$$
\tilde{w}=\hat{\theta}_{w}+\hat{\beta}_{w} x
$$

The IV-estimator of the wage elasticity is then found by estimating a labour supply equation in which wages are replaced by instrumented wages.

$$
n=\theta_{n}+\beta_{n} \tilde{w}+\mu_{n}
$$

In the practice of IV-estimation it is difficult to find instrumental variables in the strict sense of the word: i.e. variables that only have a correlation with the demand curve and no correlation with the supply curve. It is easy to see from figure 3.1 and 3.2 that a perfect instrument solves the identification problem, since filtering the data with such an instrument excludes all variation in the supply curve and leaves variation in the demand curve partly intact. Although R\&D expenditure will mainly be set by policy decisions, variations in supply will of course partially influence the actual expenditures. It therefore remains necessary to further reduce unexplained variations in the supply curve to improve estimates of the elasticities of supply and reduce effects of this identification problem. Since variations in supply are partly caused by changes in the composition of the labour force, for micro data this approach indeed yields positive wage elasticities of supply. For example, Goolsbee (1998) obtains highly significant estimates between 0.1 and 0.2 . The identification problem is largely reduced if we estimate supply curves on the basis of micro data. Shifts in the wage-supply plane of labour supply curves are caused by other supplydetermining factors, such as demographics. The demographic characteristics of the labour supply as a whole may have a variability that is too large compared with the variability of the labour demand curve, to allow identification of an aggregate labour supply curve. Micro data allow us to take the individual heterogeneity into account which determines the location of the individual labour supply curve. These individual supply curves will be subject to relatively minor shifts, as the demographic characteristics of an individual are less variable. At the same time, the position of the labour demand curve will still be relatively variable, allowing identification of the individual labour supply curve. However, as random influences in supply might 
remain to exist part of the estimations bias might still occur. The IV-method will be applied in chapters 5 and 6.

Unfortunately, the literature on estimating wage elasticities from macro data shows that empirical estimations of aggregate labour supply functions usually yield negative or insignificant wage elasticities of supply (Kniesner \& Goldsmith, 1987). As a matter of fact, Kimmel and Kniesner (1998) claim that "identifying labour supply with macro data may be impossible". This might have caused a serious problem for this study, as the most informative data available on knowledge workers in the Netherlands is the R\&D Survey of Statistics Netherlands, which is a macro dataset. However, in chapter 7 we will show that also in case of macro data a better specification of the supply structure, including its lag structure, turns out to be a remedy for the identification problem. In particular, dealing with the second econometric pitfall, the possible non-stationarity of macro-economic regressions, contributes to the reduction of the identification problem.

The non-stationarity of macroeconomic regressors is an issue which has emerged in the 1980s, see for example Nelson \& Plosser (1982). The non-stationarity of regressors is another violation of the assumptions on which the usual test-statistics of the OLS method are based. As a result, straightforward regressions between nonstationary variables lead to misleading inferences. The proper way to study causalities between non-stationary variables is to find co-integrating relationships and to estimate error correction mechanisms. As a matter of fact, according to the Engle \& Granger Representation Theorem, a co-integrating relationship implies the existence of an error correction mechanism (Engle \& Granger, 1987). Since the identification problem requires an IV-approach, we will use a combination of the IVmethod and the ECM-approach to deal with the first two econometric pitfalls. The estimation procedure for macro data (chapters $5,7,8$ ) can be described by the following equations. The wage equations are given by (3.6) and (3.7).

$$
w_{t}=\theta_{w}+\beta_{w} x_{t}+\mu_{w, t}
$$

Equation (3.6) yields super-consistent estimates of $\beta_{w}$ and $\theta_{w}$, which are inserted in equation (3.7).

$$
\Delta w_{t}=a_{w} \Delta x_{t}+Y_{w}\left(w_{t-1}-\hat{\theta}_{w}-\hat{\beta}_{w} x_{t-1}\right)+\varepsilon_{w, t}
$$

Since wages and R\&D expenditure are expressed in natural logarithms, we can interpret both $\alpha_{w}$ and $\beta_{w}$ as R\&D expenditure elasticities of wages. Since $a_{w}$ measures the immediate effect of the change in R\&D expenditure on the change in wages, it can be interpreted as a short-term elasticity. The coefficient $\beta_{w}$ represents the long-term equilibrium relationship between wages and R\&D expenditure and can therefore be interpreted as a long-term elasticity. The parameter $\gamma_{w}$ indicates the 
speed of adjustment to the long-term equilibrium. After (3.7) is estimated, we use the results to form an instrumental variable version of wages, which is used for the estimation of the labour supply equations (3.8) and (3.9), yielding the wage elasticities of the supply of R\&D workers.

$$
\begin{gathered}
n_{t}=\theta_{n}+\beta_{n} \tilde{w}_{t}+\mu_{n, t} \\
\Delta n_{t}=\alpha_{n} \Delta \tilde{w}_{t}+\mathrm{V}_{n}\left(n_{t-1}-\hat{\theta}_{n}-\hat{\beta}_{n} \tilde{w}_{t-1}\right)+\varepsilon_{n, t}
\end{gathered}
$$

The estimation of the R\&D expenditure elasticity of R\&D employment does not suffer from an identification problem, but the non-stationarity still calls for the estimation of an ECM. The short-term and long-term R\&D expenditure elasticities of the employment of R\&D workers are estimated on the basis of equations (3.10) and (3.11).

$$
\begin{gathered}
n_{t}=\theta+\beta x_{t}+\mu_{t} \\
\Delta n_{t}=\alpha \Delta x_{t}+Y\left(n_{t-1}-\hat{\theta}-\hat{\beta} x_{t-1}\right)+\varepsilon_{t}
\end{gathered}
$$

From a theoretical point of view, the use of dynamic models - such as error correction mechanisms - has the advantage that it enables us to disentangle the dynamic effects of R\&D expenditure on the labour market for R\&D workers. David and Hall (2000) discuss the various static and dynamic effects that may arise from R\&D spending.

A third econometric problem arises from the calculation of the wage rate. The hourly wage rate can be computed as the quotient of the earnings per year and the number of working hours per year. As a result, measurement error will introduce a spurious negative correlation between observed labour supply and wages, which implies that the estimated wage elasticity will be biased downwardly. This negative division bias is a direct consequence of the method of computing hourly wages (Rogerson \& Rupert, 1993), which makes the estimation results sensitive to measurement error. In fact this measurement error in the wages can formally be treated as shifts in the supply curve, providing similar estimation biases. This would probably be a minor problem if the variables in question are measured rather accurately. However, Mellow and Sider (1983) suggest that the measurement error in the number of hours worked sometimes amounts to about 10\%. Kimmel and Kniesner (1998) therefore suggest to compute the wage rate on the basis of a "norm" for the hours worked, 
instead of the reported number of hours worked. As a result, measurement error in the number of hours worked will not translate into a negative division bias. This approach will be followed when we estimate wage elasticities from the KIvI Salary Survey in chapter 6 .

The main aim of this report is estimate the impact of R\&D expenditure on wages of knowledge workers and R\&D activities for the Netherlands. After some methodological and theoretical considerations and a reconsideration of the US evidence, in the next two chapters attention will be paid to the Dutch situation. In chapter 8 we will put the Dutch evidence in a European context. 


\section{A simple analytical model}

Although this study is primarily of an empirical nature, it is instructive to look at the issues about the relationship between R\&D expenditure, wages and employment from a theoretical perspective. It turns out that a simple partial equilibrium model of the labour market for R\&D workers yields some interesting insights into the relationship between the various key elasticities. The model can also be used to illustrate the identification problem.

Labour market reactions can only be understood as the interaction of supply and demand. Although rather basic, for a good understanding of the estimates of supply responses to changes in demand in this report, it is important to take a look at a partial labour market model:

$\log S=C_{S}+\beta_{S} \log W$

$\log D=C_{D}+\beta_{D} \log W$

in which $S$ represents supply, $D$ demand and $W$ the wage. The supply curve is upward sloping so $\beta_{S}>0$, and demand decreases with the wage, so $\beta_{D}<0$. The demand curve might be an aggregate of both public demand and private demand for labour. The parameter $\beta_{D}$ can be regarded as a kind of weighted average of the parameters in both demand curves.

Assuming equilibrium between supply and demand leads to:

$\log W=\frac{C_{D}-C_{S}}{\beta_{S}-\beta_{D}}$

and

$\log D=\log S=\frac{\beta_{S} C_{D}-\beta_{D} C_{S}}{\beta_{S}-\beta_{D}}$

The effects of wages on the supply of knowledge workers can be measured in terms of elasticities. The elasticity $E_{s}$ of supply $S$ with respect to wage $W$ can formally be defined as:

$$
E_{S}=\frac{\partial \log S}{\partial \log W}
$$

The interpretation is very convenient: it indicates the percentage change of supply in response to a wage change of $1 \%$. For example, an elasticity of 2.0 , means that a $1 \%$ increase in the wage rate leads to a $2 \%$ increase of supply. In the log-linear partial labour market model presented above, the wage elasticity of supply $E_{s}$ equals $\beta_{S}$. Reversely $E_{w}=1 / \beta_{S}$ indicates how much the wage has to be raised to increase supply with $1 \%$. This wage elasticity is however not observed as such. Observed values of the wages and supply and demand are interdependent, as mentioned 
before. Without any changes in supply and demand curve only the equilibrium point will be observed, so the slopes of the underlying curves - i.e. the elasticities - can never be identified. Therefore changes in the supply or demand curve are needed to measure the elasticities. In practice correlations between employment and wages might both be positive and negative, depending on the actual movements of the supply and demand curves. An adequate measurement of both curves has therefore been one of the classical problems in econometrics, with early attempt by Moore (1914), Wright (1915) and Lehfeldt (1915) as discussed e.g. in Morgan (1990).

As has been discussed in chapter 3 , there are two routes to derive these elasticities from market observations. For the first route it is required that the supply curve is fixed, while the demand curve shifts, due to changes in its parameters. This will generate different values of both the wage and supply, enabling an estimation of the elasticity of supply.

Formula (4.3) and (4.4) however show that when supply and demand curve move simultaneously, the underlying parameters can be estimated by relating the wages and supply/demand to the changing values in the intercepts $C_{S}$ and $C_{D}$. It is important to note that this does not provide direct estimates of the elasticities, but e.g. a shock in the demand curve (represented by a change in $C_{D}$ ) provides an estimate of $1 /\left(\beta_{S}-\beta_{D}\right)$ when related to the wage, and $\beta_{S}\left(\beta_{S}-\beta_{D}\right)$ when related to employment.

The intercepts of the supply and demand curves are theoretical concepts, however. They represent changes in supply or demand at a constant wage. To operationalise the estimation - as a second way to estimate the model - variables are needed that determine these intercepts, i.e. which influence the demand curve without influencing the supply curve and vice versa. Such variables are called instrumental variables.

Within the context of influences on wages and supply due to increased R\&D expenditure, the total or public R\&D budget is regarded as a good indicator for these changes in the demand curve. Also Goolsbee (1998) utilizes this R\&D budget to identify wage and supply responses. It should be noted however that - even assuming R\&D expenditure to be exogenous - they depend on the number of researchers employed, their wages and on material expenses. Assuming material expenditure to be proportionally related to wage costs, they can be expressed as:

$\log E R D=\log S+\log W+\log (1+\lambda)$

in which $\lambda$ represents the overhead fraction for material expenses.

Therefore

$$
\begin{aligned}
\log E R D & =\frac{\beta_{S} C_{D}-\beta_{D} C_{S}}{\beta_{S}-\beta_{D}}+\frac{C_{D}-C_{S}}{\beta_{S}-\beta_{D}}+\log (1+\lambda) \\
20 & =\frac{\left(\beta_{S}+1\right) C_{D}-\left(\beta_{D}+1\right) C_{S}}{\beta_{S}-\beta_{D}}+\log (1+\lambda)
\end{aligned}
$$


As a consequence:

$\log W=\frac{1}{\beta_{S}+1} \log E R D+\frac{1}{\beta_{S}+1} C_{S}-\frac{1}{\beta_{S}+1} \log (1+\lambda)$

Estimation of this equation yields the (empirical) R\&D expenditure elasticity of wages, as introduced in equation (2.2). In this simple analytical model, the theoretical R\&D expenditure elasticity of wages $E_{E R D}$ is directly related to the theoretical wage elasticity of supply $E_{s}\left(=\beta_{s}\right)$ :

$$
E_{E R D}=\frac{1}{\beta_{S}+1}
$$

Consequently, estimates of the R\&D expenditure elasticity of wages can be translated directly into wage elasticities of supply. Keep in mind that the connection between the two elasticities is conditional on the proportionality of non-labour expenses to wage costs, which was assumed in the theoretical model. Notice that the relationship between the R\&D expenditure elasticity of wages and the wage elasticity of supply, also implies that there is a link with the inverse of the wage elasticity: $E_{w}=E_{E R D} /\left(1-E_{E R D}\right)$.

We have shown that in this simple analytical model there is a clear connection between two of the three key elasticities of this study: the wage elasticity of supply $E_{w}$ and the R\&D expenditure elasticity of wages $E_{E R D}$

The analytical model can also be used to shed further light on the identification problem mentioned in chapter 3 . The relationship between supply and wages equals:

$\log W=\frac{1}{\beta_{S}} \log S-\frac{1}{\beta_{S}} C_{S}$

Assuming the supply curve to be constant in time and the demand curve to fluctuate, would allow direct estimation of this equation, treating the second right hand term as an error term. If the supply curve fluctuates $C_{s}$ will be positively correlated with logS and negatively correlated with the wage, however. For that reason a negative estimation bias occurs.

The equation based on R\&D expenditure equals

$\log W=\frac{1}{\beta_{S}+1} \log E R D+\frac{1}{\beta_{S}+1} C_{S}-\frac{1}{\beta_{S}+1} \log (1+\lambda)$ 
When this equation is estimated, assuming no or only modest fluctuations in the supply curve (i.e. in $C_{s}$ ), the second right hand term is treated as an error term. Neglecting this term when fluctuations in the supply curve become larger, however, might provide a positive estimation bias for the wage elasticity to be estimated. Since the intercept of the supply curve is negatively correlated with both the wage and $R \& D$ expenditure if $\beta_{D}<-1, \log E R D$ might pick up the influence of the shifting supply curve on the wage. Especially in the short run demand responses to wage fluctuations might be low and an overestimation of the effect of R\&D expenditure on wages might occur. 


\section{Evidence from the US}

Since the best evidence for significant and substantial effects of increases in R\&D expenditure on wages of knowledge workers exists for the US, the empirical analyses in this report will start by reconsidering the situation in the US. The data that are available for the estimations in this section were collected by Goolsbee for his paper in the American Economic Review in 1998. The data are from the US Current Population Survey (CPS) and cover 1968-1996. Goolsbee (1998) however only uses 1968-1994 in his analyses. The 1993 data are missing in the series.

The main empirical result Goolsbee obtains for the US is the relationship between R\&D expenditure as a fraction of GDP and annual income. He uses individual data and controls for personal characteristics. Table 5.1 provides the results. The table shows positive effects of GDP-growth, a post-college degree, and marital status on wages. Scientists earn less than engineers and experience has the usual shape: an increase of the influence of experience on wages until the age of 30 with a decrease afterwards.

The main variable in this equation however is the logarithm of total R\&D expenditure to GDP. This variable has a significant positive effect on wages, indicating that increased R\&D spending will lead to higher wages which partially absorb the additional budget. When it is assumed that material expenses are proportional to wage costs, the estimated parameter would imply that a $1 \%$ increase of the R\&D budget (as a fraction of GDP) would lead to a $0.3 \%$ increase in wages and a $0.7 \%$ increase in knowledge activities.

Based on the analytical model in the previous chapter, the wage elasticity of supply is therefore $(0.3 /(1-0.3)=) 0.43$. As explained in chapter 3 and 4 this estimate might be upwardly biased due to shifts in the supply curve or measurement errors in the wages. ${ }^{3}$ Furthermore, Goolsbee implicitly treats all individual deviations in the wages as independent, while both correlations of the error term between individuals within a certain year and autocorrelation between the years can be expected. The assumed structure of the error term might therefore easily lead to an underestimation of the standard-errors, which consequently suggest a higher level of significance than would be correct.

Goolsbee also shows that the effect of R\&D expenditure on annual income results from higher hourly wages rather than an increase in hours worked by knowledge workers. This is shown in table 5.2. The table also presents the effect of federal R\&D expenditure on annual income, hourly wages and hours worked. The effects are smaller, which could be expected, since the federal budget on R\&D is by definition smaller than the total expenditure. Joint estimation of both federal and total

3. Goolsbee (1998) estimates the wage elasticity of supply directly and obtains values between 0.1 and 0.2 . 
expenditure, leads to insignificant estimates. The reason for this is that both variables are strongly correlated, which hampers the identification of separate effects.

\section{Table 5.1}

Estimation of effect of R\&D expenditure on annual income of knowledge workers, US, 19681994

\begin{tabular}{lcc}
\hline Variable & \multicolumn{2}{c}{ estimation } \\
\hline & & \\
Constant & 9.736 & $(0.038)$ \\
Log (ERD) & 0.300 & $(0.039)$ \\
GDP & 0.472 & $(0.123)$ \\
Post-college & 0.167 & $(0.006)$ \\
Married & 0.116 & $(0.008)$ \\
Scientist & -0.120 & $(0.007)$ \\
Experience & 0.046 & $(0.000)$ \\
Experience`2 & -0.000782 & $(0.0000244)$ \\
Year & 0.002 & $(0.000492)$ \\
& & \\
\hline
\end{tabular}

Table 5.2:

Estimates of effect of total R\&D, federal R\&D expenditure and combination on annual income, hourly wages and hours worked of knowledge workers, US, 1968-1994

\begin{tabular}{lcccc}
\hline & Total ERD/GDP federal ERD/GDP & $\begin{array}{l}\text { joint } \\
\text { estimation } \\
\text { total ERD/GDP }\end{array}$ & $\begin{array}{l}\text { joint } \\
\text { estimation } \\
\text { federal ERD/GDP }\end{array}$ \\
\hline Log(income) & 0.300 & 0.234 & 0.173 & 0.107 \\
& $(0.039)$ & $(0.030)$ & $(0.109)$ & $(0.085)$ \\
Log(hourly wage) & 0.280 & 0.224 & 0.109 & 0.144 \\
Log(hours) & $(0.040)$ & $(0.032)$ & $(0.114)$ & $(0.090)$ \\
& 0.019 & 0.010 & 0.064 & -0.037 \\
& $(0.016)$ & $(0.013)$ & $(0.046)$ & $(0.036)$ \\
\hline
\end{tabular}

It is remarkable that Goolsbee only uses the 1968-1994 data, while 1968-1996 seemed to be available. R\&D expenditure and wages in 1995 and 1996 can both be regarded as relative outliers in the time series. Table 5.3 shows that by including these years the estimated effects will go down considerably.

Table 5.3

Estimates of effect of total R\&D, federal R\&D expenditure on annual income, hourly wages, and hours worked of knowledge workers, US, 1968-1996

\begin{tabular}{lcc}
\hline & Total ERD & federal ERD \\
\hline & 0.209 & 0.140 \\
Log(income) & $(0.036)$ & $(0.027)$ \\
& 0.208 & 0.148 \\
Log(hourly wage) & $(0.038)$ & $(0.029)$ \\
& 0.000 & -0.008 \\
Log(hours) & $(0.015)$ & $(0.012)$ \\
& & \\
\hline
\end{tabular}


Also the trend variable seems to play a crucial role in the estimation of the elasticities. Table 5.4 presents the estimations when no trend variable is included or when besides the year also the year-squared is included to take account for trend effects. The influence of total $R \& D$ expenditure on wages decreases the more flexible the trend is modelled, while effects of federal R\&D can only be found when at least one trend term is included. This suggests that although federal R\&D expenditure has been decreasing over time, wages tended to increase.

Table 5.4

Estimates with different trend structures of effect of total R\&D, federal R\&D expenditures on income of knowledge workers, US, 1968-1996

\begin{tabular}{lcc}
\hline Log(income) & Total ERD & federal ERD \\
\hline No trend & 0.366 & 0.016 \\
& $(0.032)$ & $(0.024)$ \\
Trend & 0.300 & 0.234 \\
& $(0.039)$ & $(0.030)$ \\
trend and trend^2 & 0.263 & 0.214 \\
& $(0.042)$ & $(0.031)$ \\
& & \\
\hline
\end{tabular}

One important source of overestimation of the significance of the effect of R\&D expenditure on wages is the assumption of independent errors term between individuals within a certain year. To use both the time-series data and the individual information optimally, the model should be estimated within a hierarchical framework. For explorative purposes in table 5.5 the estimates are presented based on aggregated yearly data. These estimates will also be most comparable with estimates for Europe and the Netherlands, in which individual data are rarely available. The table shows that the estimates of the effect of total expenditure become slightly smaller. The effect of federal expenditure decreases rather substantially. Furthermore, as expected, also the degree of significance diminishes substantially, indicating at large correlations between errors in the individual wage equation within a certain year. The effect remain significant, however.

Table 5.5

Estimates based on aggregated data with different trend structures, different time periods of effect of total R\&D, federal R\&D expenditure on income of knowledge workers, US

\begin{tabular}{lcc}
\hline & Total ERD & federal ERD \\
\hline 1968-1994 without trend & 0.171 & 0.058 \\
& $(0.067)$ & $(0.052)$ \\
$1968-1994$ with trend & 0.191 & 0.146 \\
& $(0.078)$ & $(0.065)$ \\
$1968-1996$ without trend & 0.168 & -0.045 \\
& $(0.082)$ & $(0.051)$ \\
$1968-1996$ with trend & 0.117 & 0.062 \\
& $(0.090)$ & $(0.072)$
\end{tabular}


In section 2 it has been shown that there are two ways to estimate the wage elasticity of supply. An estimation based on R\&D expenditure, which gives an indirect indication of this elasticity, tends to overestimate the elasticity. An estimation based on R\&D activities measured in units, however, tends to underestimate the effect, due to shifts in the supply curve. Table 5.6 compares both ways to estimate the effect of R\&D expenditure on wages of knowledge workers. Both equations provide significant effects. The wage elasticity of supply varies according to these two approaches between 0.187 and 0.429 . A $1 \%$ increase in R\&D expenditure leads to a $0.158-0.300 \%$ increase in wages and - if material expenses are proportional to wage costs - thus to a $0.700-0.842 \%$ increase in knowledge activities.

Table 5.6

Estimation of effect of R\&D expenditure on income of knowledge workers, US, 1968-1994, based on R\&D expenditure and R\&D units

\begin{tabular}{lcc}
\hline Variable & $\begin{array}{c}\text { Estimation Based } \\
\text { on R\&D Expenditure }\end{array}$ & $\begin{array}{c}\text { Estimation Based } \\
\text { on R\&D Units }\end{array}$ \\
\hline Constant & 9.736 & 11.771 \\
& $(0.038)$ & $(0.448)$ \\
Log (ERD) & 0.300 & Corresponds to \\
& $(0.039)$ & 0.158 \\
Log(ERD) - Log(Average Income) & Corresponds to & 0.187 \\
& 0.429 & $(0.043)$ \\
Gdp & 0.472 & 0.491 \\
& $(0.123)$ & $(0.124)$ \\
Post-college & 0.167 & 0.167 \\
& $(0.006)$ & $(0.006)$ \\
Married & 0.116 & 0.117 \\
Scientist & $(0.008)$ & $(0.008)$ \\
Experience & -0.120 & -0.120 \\
Experience ${ }^{\wedge} 2$ & $(0.007)$ & $(0.007)$ \\
Year & 0.046 & 0.046 \\
& $(0.000)$ & $(0.001)$ \\
& -0.000782 & -0.000785 \\
& $(0.0000244)$ & $(0.0000244)$ \\
& 0.002 & 0.002 \\
& $(0.000474)$ & $(0.000492)$ \\
\hline
\end{tabular}

Since the estimates suggest that increased $R \& D$ expenditure raises wages, the question arises whose wages will be affected. Table 5.7 and 5.8 therefore present a wage equation for knowledge workers in which some cross effects of R\&D expenditure with other variables are included.

Table 5.7 contains the result of a regression in which some cross-effects between the explanatory variables in the wage equation and R\&D activity are included. The first column of parameters provide the constant part of the parameter and the second column the cross-effects with R\&D expenditure, i.e. the way in which these parameters depend on R\&D activity. The table shows that although people with a post-college degree earn on average more than others, their wages will increase less as a result of $R \& D$ expansion. The higher income of married knowledge workers is not affected by increased R\&D expenditure. The wage gap between scientists and 
engineers will become smaller as a result of increased R\&D expenditure. Very interesting is the effect on the relationship between experience and wage. The table shows that wages of younger knowledge workers benefit more from intensified R\&D activities than the wages of older knowledge workers.

Table 5.7

Estimation of effect of R\&D expenditure on income of knowledge workers, some cross effects included, US, 1968-1994

\begin{tabular}{lcl}
\hline & Estimate & $\begin{array}{l}\text { estimate } \\
\text { Cross-effect with } \\
\text { Log (ERD) }\end{array}$ \\
\hline Constant & & 0.787 \\
GDP & 10.243 & $(0.422)$ \\
Post-college & $(0.104)$ & \\
Married & 0.406 & -0.145 \\
Scientist & $(0.125)$ & $(0.066)$ \\
Experience & 0.305 & -0.054 \\
Experience^2 & $(0.062)$ & $(0.090)$ \\
Year & 0.170 & 0.180 \\
Year^2 & $(0.086)$ & $(0.077)$ \\
& -0.289 & -0.063 \\
& $(0.073)$ & $0.010)$ \\
& 0.104 & 0.0014 \\
& $(0.009)$ & $(0.00027)$ \\
& -0.002 & \\
& $(0.00025)$ & \\
\hline
\end{tabular}

Table 5.8 provides more details about the differences by age. In this equation, dummy variables are included for 5-year-age groups. Workers below 30 earn substantially less than more experienced workers. The highest income is found in the groups between 35 and 40 and between 45 and 50 . These groups, however, benefit least from increased R\&D expenditure. Wages of young workers might increase with an elasticity above one. It seems to suggest a strong competition between employers for these young knowledge workers. The increase in wages will force some employers to recruit older workers, therefore inducing a spill-over-effect that will also increase their wages.

The estimates are based on wage and expenditure levels. Estimation is therefore possibly hampered by autocorrelation, while the estimates should be interpreted as long run elasticities. To get rid of this autocorrelation and to focus on short term elasticities, it is possible to estimate the aggregated data in yearly changes. Table 5.9 shows however that these estimates show no significant effects anymore. Since short run elasticities are expected to be higher than long run elasticities, estimation problems seem to be present. It is however not possible to indicate whether these problems occur in the equation based on levels or the equation based on yearly changes. Besides influences due to a shifting supply curve, the problems could be 
caused by delayed wage adjustments. Estimation based on an error correction model could therefore shed light on this issue.

Table 5.8

Estimation of effect of R\&D expenditure on income of knowledge workers, extended cross effects included, US, 1968-1994

\begin{tabular}{|c|c|c|}
\hline & Estimate & $\begin{array}{l}\text { estimate of } \\
\text { Cross-effect with } \\
\text { Log (ERD) }\end{array}$ \\
\hline Constant & $\begin{array}{l}11.421 \\
(0.433)\end{array}$ & \multirow{14}{*}{$\begin{array}{c}0.315 \\
(0.139) \\
(0.126) \\
-0.046 \\
(0.066) \\
-0.035 \\
(0.091) \\
0.197 \\
(0.077) \\
0.572 \\
(0.158) \\
0.231 \\
(0.130) \\
-0.195 \\
(0.130) \\
-0.415 \\
(0.135) \\
-0.177 \\
(0.136) \\
-0.320 \\
(0.139) \\
0.028 \\
(0.144)\end{array}$} \\
\hline GDP & 0.425 & \\
\hline Post-college & $\begin{array}{c}0.120 \\
(0.061)\end{array}$ & \\
\hline Married & $\begin{array}{c}0.147 \\
(0.086)\end{array}$ & \\
\hline Scientist & $\begin{array}{l}-0.305 \\
(0.073)\end{array}$ & \\
\hline Age $<25$ & $\begin{array}{l}-1.281 \\
(0.147)\end{array}$ & \\
\hline $25 \leq$ age $<30$ & $\begin{array}{l}-0.647 \\
(0.121)\end{array}$ & \\
\hline $30 \leq$ age $<35$ & $\begin{array}{l}-0.108 \\
(0.122)\end{array}$ & \\
\hline $35 \leq$ age $<40$ & $\begin{array}{c}0.245 \\
(0.126)\end{array}$ & \\
\hline $40 \leq$ age $<45$ & $\begin{array}{c}0.078 \\
(0.127)\end{array}$ & \\
\hline $45 \leq$ age $<50$ & $\begin{array}{c}0.250 \\
(0.129)\end{array}$ & \\
\hline $50 \leq$ age $<55$ & $\begin{array}{l}-0.035 \\
(0.134)\end{array}$ & \\
\hline Year & $\begin{array}{l}-0.024 \\
(0.010)\end{array}$ & \\
\hline Year^2 & $\begin{array}{l}0.00016 \\
(0.000062)\end{array}$ & \\
\hline
\end{tabular}

Table 5.9

Estimates based on yearly changes in aggregated data for different time periods of effect of total R\&D, federal R\&D expenditure on income of knowledge workers, US (constant term included)

\begin{tabular}{lcc}
\hline & Total ERD & federal ERD \\
\hline \multirow{2}{*}{$1968-1994$} & 0.041 & 0.116 \\
& $(0.219)$ & $(0.185)$ \\
$1968-1996$ & 0.005 & 0.073 \\
& $(0.215)$ & $(0.180)$ \\
\hline
\end{tabular}

Unit root tests (Dickey-Fuller) indicate that annual income is integrated of order 1 for all age groups. Total R\&D expenditure is also I(1), but federal R\&D expenditure is stationary. Nevertheless, we will estimate similar error correction mechanisms for federal $R \& D$ expenditure as for total R\&D expenditure. 
Cointegration of total R\&D expenditure and annual income is accepted for all age groups, except for the $25-30$ cohort. Table 5.10 shows the estimated R\&D expenditure elasticities of wages (annual income), according to equations (3.6) and (3.7). Except for the 35-40 age bracket, all long-term elasticities are positive. All adjustment coefficients are significant and have the correct negative sign. However, most short-term elasticities are negative. For the group of R\&D workers as a whole the short-term elasticity is not significantly different from zero, so we may infer that a $1 \%$ increase in (total) R\&D expenditure has little short-term effect on annual income and leads to a $0.17 \%$ increase in income in the long run.

Table 5.10

R\&D expenditure elasticities of wages (annual income)

\begin{tabular}{|c|c|c|c|c|c|}
\hline Country & $\begin{array}{l}\text { short-term } \\
\text { elasticity } \alpha\end{array}$ & $\begin{array}{l}\text { adjustment } \\
\text { speed } Y\end{array}$ & LM & $\mathrm{R}^{2}$ & $\begin{array}{l}\text { long-term } \\
\text { elasticity } \beta\end{array}$ \\
\hline Age $<25$ & $(0.63)$ & $-0.79^{*}(0.23)$ & 0.30 & 0.37 & 0.77 \\
\hline $25 \leq$ age $<30$ & $(0.29)$ & $-0.56^{*}(0.20)$ & 0.07 & 0.35 & 0.49 \\
\hline $30 \leq$ age $<35$ & $-0.87 \quad(0.56)$ & $-0.78^{*}(0.27)$ & 0.65 & 0.31 & 0.10 \\
\hline $35 \leq$ age $<40$ & $-0.87^{*}(0.32)$ & $-0.86^{*}(0.21)$ & 0.10 & 0.44 & -0.16 \\
\hline $40 \leq$ age $<45$ & $-0.48 \quad(0.36)$ & $-0.73^{*}(0.20)$ & 1.44 & 0.38 & 0.09 \\
\hline $45 \leq$ age $<50$ & $-0.62^{*}(0.27)$ & $-1.47^{*}(0.20)$ & $8.94^{*}$ & 0.72 & 0.03 \\
\hline $50 \leq$ age $<55$ & $0.72^{*}(0.31)$ & $-1.04^{*}(0.22)$ & 0.66 & $\begin{array}{l}0.51 \\
0.48\end{array}$ & 0.40 \\
\hline
\end{tabular}

Estimation method: OLS, standard errors between brackets, asterisk denotes 5\% significance LM: Breusch-Godfrey Lagrange Multiplier test for first order serial correlation, asterisk denotes $5 \%$ significance

Table 5.11

Federal R\&D expenditure elasticities of wages (annual income)

\begin{tabular}{|c|c|c|c|c|c|}
\hline Country & $\begin{array}{l}\text { short-term } \\
\text { elasticity } \alpha\end{array}$ & $\begin{array}{l}\text { adjustment } \\
\text { speed } Y\end{array}$ & LM & $\mathrm{R}^{2}$ & $\begin{array}{l}\text { long-term } \\
\text { elasticity } \beta\end{array}$ \\
\hline $\begin{array}{l}\text { Age }<25 \\
25 \leq \text { age }<30 \\
30 \leq \text { age }<35 \\
35 \leq \text { age }<40 \\
40 \leq \text { age }<45 \\
45 \leq \text { age }<50 \\
50 \leq \text { age }<55 \\
\text { All ages }\end{array}$ & $\begin{array}{rr}0.79 & (0.45) \\
0.35^{*} & (0.15) \\
-0.21 & (0.24) \\
-0.34 & (0.23) \\
-0.21 & (0.26) \\
-0.00 & (0.18) \\
0.27 & (0.24) \\
-0.05 & (0.15)\end{array}$ & $\begin{array}{ll}-0.60^{*} & (0.19) \\
-0.21 & (0.13) \\
-0.66^{\star} & (0.21) \\
-0.70^{\star} & (0.20) \\
-0.65^{\star} & (0.20) \\
-1.40^{\star} & (0.20) \\
-0.55^{\star} & (0.19) \\
-0.68^{*} & (0.21)\end{array}$ & $\begin{array}{l}0.96 \\
0.50 \\
0.49 \\
0.57 \\
1.90 \\
7.73^{*} \\
1.10 \\
1.64\end{array}$ & $\begin{array}{l}0.34 \\
0.35 \\
0.33 \\
0.35 \\
0.32 \\
0.70 \\
0.30 \\
0.35\end{array}$ & $\begin{array}{l}0.46 \\
0.35 \\
0.24 \\
0.00 \\
0.00 \\
0.12 \\
0.04 \\
0.10\end{array}$ \\
\hline
\end{tabular}

Estimation method: OLS, standard errors between brackets, asterisk denotes $5 \%$ significance LM: Breusch-Godfrey Lagrange Multiplier test for first order serial correlation, asterisk denotes $5 \%$ significance

As mentioned earlier, federal R\&D expenditure is a stationary series. However, we will estimate error correction mechanisms in the same way as for total R\&D expenditure. Table 5.11 shows the federal R\&D expenditure elasticities of wages (annual income). Most long-term elasticities are positive with a significant adjustment speed coefficient. The short-term elasticities are not significantly different from zero, except for the age group 25-30. A $1 \%$ increase in federal $R \& D$ expenditure leads to 
a $0.1 \%$ increase in overall annual income in the long run, while the short-term effect is probably even smaller. The effects on the annual income of R\&D workers below the age of 30 are relatively large, both in the short run $(0.4-0.8 \%)$ and in the long run $(0.4-0.5 \%)$. These error correction estimates however seem to confirm that wage responses in reaction to additional $R \& D$ expenditure, as reported by Goolsbee (1998), are long run rather than short run effects. 


\section{Evidence from Dutch cross-sectional micro-data}

As has been put forward in chapter 3 , supply elasticities of R\&D expenditure can be estimated, both from cross-sectional and time series data. Since the investigation of the labour market for R\&D workers in the Netherlands is at the core of this report, we will apply both approaches for the Netherlands.

Since 1987 NSS Research \& Consultancy regularly performs a questionnaire survey for the Royal Institute of Engineers in the Netherlands (Koninklijk Instituut van Ingenieurs, Klvl)) among its members. The purpose of this survey is to get a picture of the primary and secundary terms of employment of university-level engineers (KIvl, 1998). The fourth and most recent survey, relating to 1997 , was kindly made available to us by KIvl. It has a response of 2,091 , which is $28 \%$ of the membership of KIvI.

The KIVl Salary Survey (KIvl Salarisenquête) is not specifically aimed at knowledge workers, but at university-level engineers. This means that research scientists educated at non-technical universities are not in the sample, neither are knowledge workers from social sciences. At the same time, most of the university-level engineers are not research engineers. As mentioned earlier, about half of all technically educated workers in the Netherlands do not work in technical occupations, let alone technical R\&D work. Only about one out of five university-level engineers has R\&D as the main activity (KIVI, 1998).

Another important limitation of this dataset is that it allows us to study labour supply only in terms of hours worked by the current group of university-level engineers. Since it does not seem to be justified to compare the supply of R\&D workers in different sectors the survey does not provide information on the additional supply of a possible inflow of engineers as a response to wage changes, neither in terms of persons, nor in terms of full-time equivalents. As a matter of fact, the survey does not contain any time series information and is therefore of limited use in understanding the dynamics of the labour market for knowledge workers.

By comparing different sectors of R\&D activity, we can use the 1997 dataset to estimate long-run elasticities. The assumption underlying this comparison is that engineers in all sectors will have similar supply behaviour, so the supply function can be regarded as constant. Short-run elasticities would require time series information, which even if available would be too short, since there exist only three previous KIvl Surveys. Also, it is not a panel. Kimmel and Kniesner (1998) argue that it is important to distinguish between wage elasticities of supply by gender and marital status. However, as $95 \%$ of the membership of KIvl consists of men, we will not make this distinction.

With the idea of estimating elasticities with the IV-method in mind, we start the empirical analysis with wage equations. Following the econometric modelling 
approach proposed by Hendry (Gilbert, 1986), we have systematically worked from a large model to a nested small model. The resulting wage equation and labour supply equation are described in the following two sections.

\subsection{The wages of university-level engineers}

The first wage equation that we estimated used a large amount of variables which may explain wages. These variables are the economic sector in which the engineer is employed, the field of study in which the engineer is educated, the function that he performs within the organization, the size of the organization, the sectoral R\&D expenditure, additional academic degrees (such as PhD's and MBA's), gender and experience. Since we are interested in wages, we have excluded self-employed engineers from the sample. The average sectoral $R \& D$ expenditure per FTE researcher has been taken from the R\&D Survey of Statistics Netherlands and matched to the sectoral classification of the KIvl Survey as good as possible. It should also be noted that the R\&D Survey data refer to 1996, since the 1997 data were not yet available. As mentioned earlier, the wage equation will at a later stage also be used as an auxiliary regression equation for the IV-estimation of elasticities from the labour supply equation. The wages in the labour supply equation will be measured based on a 40 hour norm for weekly hours, in order to avoid negative division bias in the estimate of the wage elasticity. Therefore the wage equation is directly applicable for the IV-estimation procedure if we measure wages in the same manner, i.e. based on a 40 hour norm for weekly hours. We have performed similar wage equation regressions with wages based on contractual weekly hours, but there are only minor differences in the results.

The estimation results from the first wage equation (not tabulated here) were used to specify a smaller, nested model as the second wage equation to be estimated. At this stage, we focussed on reducing the number of variables by combining categories which appear to have a similar effect on wages, especially if there was a lack of statistical significance for the separate categories. However, there were certain categories of special interest to us that we kept in the analysis, in particular the type of education and R\&D functions. The estimation results suggested that the function within the organization can be divided in two groups: management and commerce on one hand, and the others on the other hand. Since we are particularly interested in R\&D functions, we distinguished between three categories in the second regression and kept R\&D as a separate category. With respect to the size of the organization, the categories could be consolidated into three classes: below 50 persons, from 50 to 10,000 persons and from 10,000 to 25,000 persons.

The estimation results of the second wage equation (not tabulated here) showed again that the field of study does not have a significant effect on wages, so we removed them for the third wage regression. We could have done this earlier, but for the objective of this study these variables are of interest. For example, in the first wage equation the coefficient for civil engineers came close to being significantly negative. However, it was clear by now that the educational variables could be 
dropped from the empirical analysis. There were two interesting results from the third wage equation (not shown here): sectoral R\&D expenditure does not have a significant impact on wages and the wages of sectoral R\&D workers are, ceteris paribus, equal to other university-level engineers.

For the fourth and final wage equation (table 6.1), we removed the other insignificant variables: the dummies for size over 50 persons, functions other than management/commercial (including R\&D), additional academic degrees, sectoral R\&D expenditure and the following sectors: Other Manufacturing Industries, Public Works, Other Public Services, Other Organizations. We kept the insignificant gender-variable with the later application of the IV-method in mind: the labour supply function has a gender-dummy. The estimation results in table 6.1 show that all the variables in the fourth and final wage equation are significantly different from zero.

Table 6.1

Fourth and Final Wage Equation

\begin{tabular}{|c|c|c|}
\hline Variable & coefficient & standard error \\
\hline \multicolumn{3}{|l|}{$\begin{array}{l}\text { Constant } \\
\text { Economic sector: (reference }=\text { other sectors) }\end{array}$} \\
\hline Electrotechnical & $0.191^{*}$ & 0.056 \\
\hline Metal, ship- and machine-building & $0.187^{*}$ & 0.046 \\
\hline Chemical, oil & $0.404^{*}$ & 0.047 \\
\hline Construction & $0.285^{*}$ & 0.057 \\
\hline Gas, electric and water & $0.238^{*}$ & 0.083 \\
\hline Transportation and communication & $0.212^{\star}$ & 0.078 \\
\hline \multicolumn{3}{|l|}{ Engineering agencies, architectural agencies } \\
\hline consultancy, patents & $0.125^{\star}$ & 0.038 \\
\hline Software & $0.161^{*}$ & 0.052 \\
\hline Other private services & $0.200^{*}$ & 0.069 \\
\hline \multicolumn{3}{|l|}{ Function: (reference = other functions, incl. R\&D) } \\
\hline Management/commercial & $0.256^{*}$ & 0.027 \\
\hline \multicolumn{3}{|l|}{ Size of the organization: (reference $=>50$ ) } \\
\hline$<50$ people & $0.414^{\star}$ & 0.038 \\
\hline \multicolumn{3}{|l|}{ Other variables: } \\
\hline Experience & $0.061^{\star}$ & 0.003 \\
\hline The square of experience & $-0.001^{*}$ & 0.000 \\
\hline \multirow{2}{*}{ Gender (female $=1$ ) } & -0.100 & 0.064 \\
\hline & R-square $=0.473$ & $\begin{array}{l}\text { adjusted R-square } \\
=0.469\end{array}$ \\
\hline
\end{tabular}

\subsection{The wage elasticities of the supply of university-level engineers}

Wage elasticities can be estimated from labour supply functions. We use the hourly wage computed on the basis of a norm for working hours per week to avoid negative division bias. Labour supply is expressed as the contractual number of working hours per year, which is the product of relative size of the individual contractual number of working hours and the number of working days per year according to a standard contract, with a correction for the contractual number of vacation days and ADV-days. Table 6.2 shows both the OLS results and the IV results. The IV method uses the fourth and final wage equation established in the preceding section. 
Besides the hourly wage, we use experience and gender as explanatory variables. Experience serves a proxy for wealth.

Table 6.2

Labour supply equation with correction for vacation-days and ADV-days

Dependent variable:

log labour supply

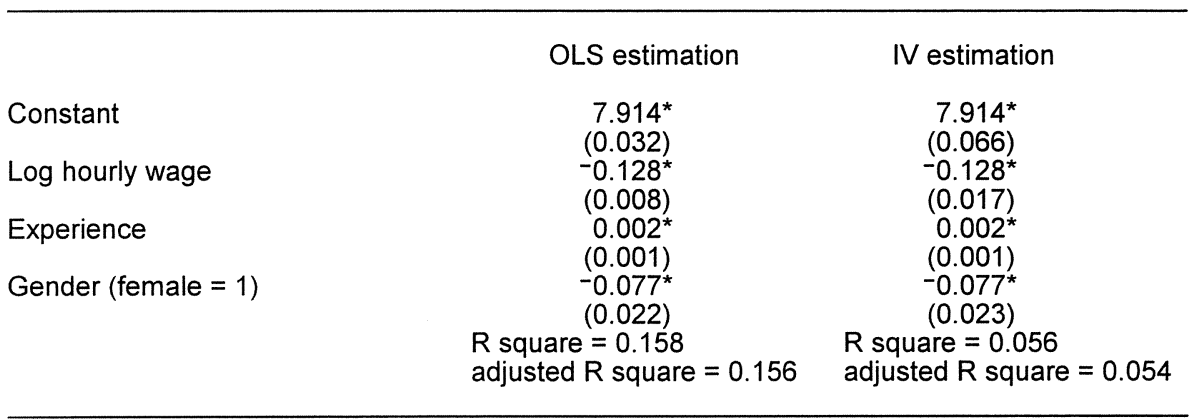

If we compare the estimated coefficients from both estimation methods, we see that they yield identical results after rounding to two decimals. The adjusted $R^{2}$ is low in both cases, but lower for the IV-method (0.054) than for the OLS-method (0.156). In both regressions all coefficients are significantly different from zero. The estimated wage elasticity is negative $(-0.128)$, which would suggest a backward bending supply curve.

The supply of labour has been corrected for vacation-days and ADV-days. It is interesting to see what happens if we do not make this correction. In this case the effect of the wage rate on the labour supply works via the individual contractual number of working hours as a fraction of a standard contract. In table 6.3 we show both the OLS and the IV-estimations.

Table 6.3

Labour supply equation without correction for vacation-days and ADV-days

Dependent variable:

log labour supply

\begin{tabular}{lcc}
\hline & OLS estimation & IV estimation \\
Constant & $6.511^{*}$ & $6.110^{*}$ \\
Log hourly wage & $(0.040)$ & $(0.088)$ \\
Experience & $0.295^{\star}$ & $0.402^{\star}$ \\
Gender (female = 1) & $(0.010)$ & $(0.023)$ \\
& $-0.008^{\star}$ & $-0.013^{\star}$ \\
& $(0.001)$ & $(0.001)$ \\
& 0.027 & 0.050 \\
& $(0.029)$ & $(0.030)$ \\
$=$ & R square $=0.178$ \\
& R square $=0.354$ & \\
& adjusted R square $=0.352$ & adjusted R square $=0.176$ \\
\hline
\end{tabular}


The adjusted $R^{2}$ is considerably higher: 0.176 in case of the IV regression has and 0.352 in case of the OLS regression. The wage elasticities are positive and significant. The IV-method yields an elasticity of 0.402 , while the OLS-method results in a somewhat smaller elasticity of 0.295 . Experience has a significantly negative coefficient for both methods $(-0.008$ for OLS, -0.013 for IV), which suggests that experience works as a proxy for wealth. The coefficient for gender is insignificant for both estimation methods.

How do we interpret the difference between the results with and without corrections for vacation-days and ADV-days? The labour contract offers two main channels through which wages could affect the supply of labour: the relative size of the individual contract and the number of contractual vacation-days and ADV-days per year. Table 6.3 shows the effects through both channels, while table 6.4 only tracks the effect on the contractual number of working hours per week. The estimation results from both tables suggest that university-level engineers with higher hourly wages have relatively more contractual working hours, but this is more than compensated by a higher number of vacation-days and ADV-days. As a result, the contractual number of working hours per year is lower.

In order to confirm this suspicion, we also performed regressions with the relative size of the contract and contractual holidays and ADV-days per year as dependent variables. Table 6.4 shows the OLS-results of a regression on hourly wages with contractual working hours per week as a dependent variable. The wage elasticity is significantly positive, confirming the positive effect of wages on the relative size of the contract.

Table 6.4

Contractual working hours per week as a function of hourly wages

Dependent variable:

log contractual working hours per week

\begin{tabular}{lc}
\hline & OLS estimation \\
Constant & $2.599^{\star}$ \\
& $(0.040)$ \\
Log hourly wage & $0.295^{\star}$ \\
Experience & $(0.010)$ \\
Gender (female = 1) & $-0.008^{\star}$ \\
& $(0.001)$ \\
& 0.027 \\
& $(0.029)$ \\
& R square $=0.354$ \\
& adjusted R square $=0.352$ \\
\hline
\end{tabular}

Notice the similarity between table 6.4 and the first column of table 6.3: the dependent variable is a simple multiplication by a constant.

Table 6.5 shows the OLS-results of a regression on hourly wages with contractual vacation-days and ADV-days per year as a dependent variable. The wage elasticity 
is significantly positive, confirming the positive effect of wages on contractual vacation-days and ADV-days per year.

The conclusion that can be drawn from the estimation results is that higher wages do lead to an increase in the individual number of working hours per week in relation to a standard contract, but at the same time it increases the number of vacation- and ADV-days per year. The net result of higher wages is therefore a decrease in the number of working hours per year. An important qualification of this conclusion is that the KIvl survey registrates the contractual working hours and working days, not the actual amount of work. The contractual working hours will in reality often be a lower bound for the actual number of hours worked. Hence, by using data on contractual quantities, we underestimate the effect of higher wages on the actual number of working hours per year. This implies that the wage elasticities of the supply of actual working hours by university-level engineers may in fact be positive.

Table 6.5

Contractual vacation-days and ADV-days per year as a function of hourly wages

Dependent variable:

log contractual vacation-days and ADV-days per year

OLS estimation

\section{Constant}

Log hourly wage

$1.507^{\star}$

$(0.074)$

$0.541^{*}$

$(0.019)$

Experience

$-0.011^{\star}$

(0.001)

$0.144^{*}$

Gender (female $=1$ ) 


\section{Evidence from Dutch macro time series}

In the previous chapter it has been shown that the individual supply of labour in terms of hours worked can be investigated on the basis of cross-sectional micro data. To grasp the effects on total supply, also involving the number of workers and the dynamics of supply, however, time-series data are needed. In this chapter we therefore extend the analyses of the Dutch labour market for knowledge workers by such time series analyses.

A macro data set which is specifically aimed at knowledge workers in the Netherlands is the R\&D Survey (R\&D Enquête) of Statistics Netherlands (Centraal Bureau voor de Statistiek). This annual survey is aimed at collecting data on R\&D expenditure and R\&D employment in the various sectors of the Dutch economy. Data on gross wage expenditure are available, which makes the R\&D Survey suited for our purposes. Three variables for each of 10 sectors of the Dutch economy and for the aggregate of these sectors, are constructed from the R\&D Survey for the empirical analysis in this chapter. The R\&D Survey distinguishes between 21 sectors, which we consolidated to 10 sectors, as shown in table 7.A.1 of Appendix 7.A. We compute real annual R\&D expenditure, with base year 1990, deflating by $\mathrm{PPI}$. R\&D employment is measured in terms of R\&D workers, expressed in annual full-time equivalents (FTEs). The real gross annual wage rate is computed as the quotient of the annual gross wage costs in real terms (base year $=1990$, deflated by $\mathrm{CPI}$ ) and R\&D employment. Table 7.1 gives an impression of the nominal figures for R\&D employment, R\&D expenditure and gross wage expenditure in 1993.

Table 7.1 shows that metal industries, chemical industries, universities and government institutions account for $81 \%$ of R\&D employment, $81 \%$ of R\&D expenditure and $78 \%$ of gross wage expenditure in the Netherlands. As expected the gross wage expenditure per FTE in the public sector is below the national average. However, the variation in gross wage expenditure per FTE does not only originate from the wage differential between the public and the private sector, but also from the demographic, occupational and educational composition of the sectoral R\&D labour forces. We should keep in mind that R\&D workers do not only include the research scientsists and engineers, but also technicians and support staff, such as secretaries. The gross wage expenditure as a percentage of R\&D expenditure is very similar across sectors and amounts about $60 \%$. The metal and chemical industries are somewhat below the other sectors as about $50 \%$ of R\&D expenditure is associated with wages.

Estimating wage elasticities of labour supply from macro data is hampered by the identification problem, see for example Kniesner and Goldsmith (1987). More recently, Kimmel and Kniesner (1998) state that "Identifying labor supply with macro data may be impossible. There is much macro empirical research acknowledging the identification problem in labor supply and attempting to find the reasons underlying the difficulty in separating the labor supply responses to macro demand 
disturbances". However, Hamermesh (1999) suggests that recent developments in dynamic econometrics, which have been applied successfully in macroeconomics and finance, deserve more attention from labour economists. In this chapter, we show that applying cointegration techniques can be a fruitful approach to deal with the identification problem of estimating wage elasticities of supply from macro data. 


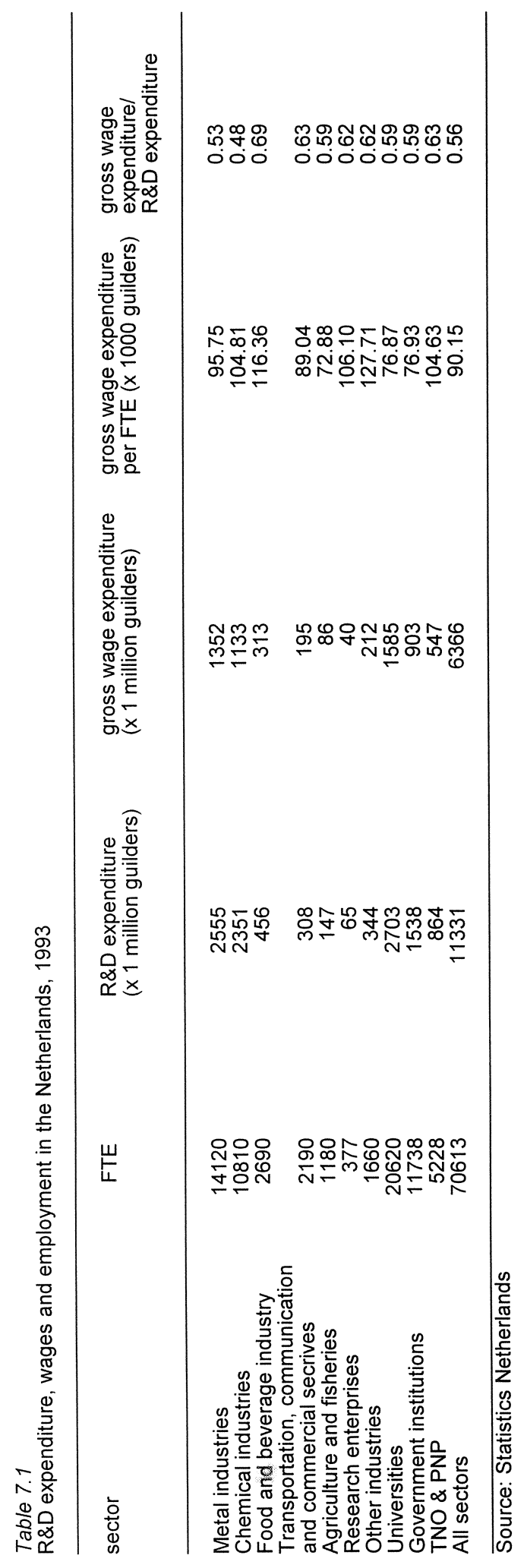


Our approach follows the traditional route of first estimating a wage equation to form instrumental variables for the estimation of the labour supply equation. However, from unit root tests it appears that the variables involved, R\&D expenditure, wages and labour supply are non-stationary. This implies that the appropriate way to apply the instrumental variable approach is to try to find cointegrating relationships between the non-stationary variables. In other words, both the wage equation and the labour supply equation are estimated in the form of error correction mechanisms. Each error correction mechanism is estimated by the two step approach by Engle and Granger (1987). As a result, the estimation procedure that we use in this chapter to obtain wage elasticities of the supply of knowledge workers can be summarized by equations (7.1)-(7.4). The three variables of interest are expressed in natural logarithms: we use $x_{t}$ to denote $R \& D$ expenditure, $w_{t}$ to denote wages and $n_{t}$ for R\&D employment. In order to avoid problems with changes in classifications, which might cause serious problems for sensitive models such as error correction mechanisms, we use data from 1973 to 1993. Keep in mind that in this chapter, wages refer to real gross annual wage expenditure per FTE, whereas in the previous chapters, wages referred to hourly wages.

The wage equations are given by (7.1) and (7.2).

$$
w_{t}=\theta_{w}+\beta_{w} x_{t}+\mu_{w, t}
$$

Equation (7.1) yields super-consistent estimates of $\beta_{w}$ and $\theta_{w}$, which are inserted in equation (7.2).

$$
\Delta w_{t}=a_{w} \Delta x_{t}+Y_{w}\left(w_{t-1}-\hat{\theta}_{w}-\hat{\beta}_{w} x_{t-1}\right)+\varepsilon_{w, t}
$$

Since wages and R\&D expenditure are expressed in natural logarithms, we can interpret $\alpha_{w}$ and $\beta_{w}$ as $R \& D$ expenditure elasticities of wages. Since $\alpha_{w}$ measures the immediate effect of the change in R\&D expenditure on the change in wages, it can be interpreted as a short-term elasticity. The coefficient $\beta_{w}$ represents the long-term equilibrium relationship between wages and R\&D expenditure and can therefore be interpreted as a long-term elasticity. The parameter $Y_{w}$ indicates the speed of adjustment to the long-term equilibrium.

After (7.2) is estimated, we use the results to form an instrumental variable version of wages, which is used for the estimation of the labour supply equations (7.3) and (7.4), yielding the wage elasticities of the supply of R\&D workers. 


$$
\begin{gathered}
n_{t}=\theta_{n}+\beta_{n} \tilde{w}_{t}+\mu_{n, t} \\
\Delta n_{t}=\alpha_{n} \Delta \tilde{w}_{t}+\mathrm{v}_{n}\left(n_{t-1}-\hat{\theta}_{n}-\hat{\beta}_{n} \tilde{w}_{t-1}\right)+\varepsilon_{n, t}
\end{gathered}
$$

Unit root tests (Dickey-Fuller) reject the stationarity of R\&D expenditure, wages and R\&D employment in all ten sectors of the Dutch economy and the aggregate level (all sectors combined). The corresponding first differences are all stationary, hence we are dealing with I(1)-variables.

The R\&D expenditure elasticities of wages estimated from equations (7.1) and (7.2) are summarized in table 7.2. Each row contains the results for a specific sector, indicated by the first column. The final row displays the estimation results at the aggregate level (all sectors). The last column shows the long-term elasticity estimated from equation (7.1). Since the test statistics from that equation do not have standard distributions, due to the non-stationarity of the variables involved, standard errors are not added to the estimated coefficient. The remaining columns show the estimated coefficients from equation (7.2), with corresponding standard errors, the Breusch-Godfrey Lagrange Multiplier test for first order serial correlation and the $R^{2}$. The estimated coefficients from (7.2) are the short-term elasticity and the adjustment speed at which wages return to the long-term equilibrium relationship with R\&D expenditure.

Table 7.2 shows that all estimated short-term elasticities are positive and significant at the $5 \%$ level. Cointegration of R\&D expenditure and wages is rejected (DickeyFuller tests, not reported here) in only four sectors: transport, communication and commercial services, agriculture and fisheries, research enterprises and government institutions. At the aggregate level cointegration is accepted. Despite the encouraging results of the cointegration tests, the estimated adjustment speed coefficients are insignificant in about two thirds of the sectors, among which the four sectors for which cointegration was rejected. On the other hand, all adjustment speed coefficients have the plausible negative sign. We do not drop the disequilibrium term from regression equation (7.2), since this may introduce omitted variable bias in the estimation of the short-term elasticity. Possible non-stationarity of the disequilibrium term may not be much of a problem, as the weak power of DickeyFuller tests often leads to an an incorrect rejection of cointegration. At the aggregate level the adjustment speed coefficient is significant, hence we conclude that there is a long-term equilibrium relationship between wages and R\&D expenditure, although the speed at which wages return to the equilibrium level is difficult to estimate precisely in various sectors. With exception of a few sectors, the error correction mechanism adequately captures the short-term and long-term dynamics as indicated by the low $L M$-values. The $R^{2}$ ranges between 0.43 and 0.95 , which is satisfactory. 
At the aggregate level, the short-term elasticity is 0.52 and the long-term elasticity is 0.38 . At the sector level, the short-term elasticities vary between 0.36 and 1.06 , while the long-term elasticities range from 0.10 to 0.97 . In about two thirds of the sectors, the long-term elasticity is smaller than the short-term elasticity. We conclude that in most sectors a permanent increase in R\&D expenditure has an upward effect on wages which is somewhat smaller in the long run. The largest short-term elasticities are found for food and beverage (1.06) and TNO \& PNP (1.00). In these sectors R\&D expenditure has relatively strong upward effects on wages within one year. As a matter of fact, the food and beverage industry is the sector where wages comprise the highest share of R\&D expenditure $(69 \%)$, as was shown in table 7.1. Short-term elasticities smaller than 0.50 hold for metal industries and government institutions. In these sectors R\&D expenditure has a relatively small upward effect on wages in the short run. The largest long-term elasticity is found for research enterprises (0.97), although the adjustment speed coefficient is difficult to estimate precisely. Long-term elasticities smaller than 0.50 hold for four sectors: metal industries, transport, communication and commercial services, universities and government institutions.

Table 7.2

R\&D expenditure elasticities of wages

\begin{tabular}{|c|c|c|c|c|c|c|c|}
\hline $\begin{array}{l}\text { Sector } \\
\text { Metal industries }\end{array}$ & \multicolumn{2}{|c|}{$\begin{array}{l}\text { short-term } \\
\text { elasticity } \alpha\end{array}$} & \multicolumn{2}{|c|}{$\begin{array}{l}\text { adjustment } \\
\text { speed } y\end{array}$} & $\begin{array}{l}\text { LM } \\
\\
\begin{array}{l}0.66 \\
4.27^{*}\end{array}\end{array}$ & $\begin{array}{l}\mathrm{R}^{2} \\
0.65 \\
0.68\end{array}$ & $\begin{array}{c}\text { long-term } \\
\text { elasticity } \beta\end{array}$ \\
\hline $\begin{array}{l}\text { Metal industries } \\
\text { Chemical industries } \\
\text { Food and beverage } \\
\text { industry } \\
\text { Transport, communication } \\
\text { and commercial services } \\
\text { Agriculture and fisheries } \\
\text { Research enterprises } \\
\text { Other industries } \\
\text { Universities } \\
\text { Government institutions } \\
\text { TNO \& PNP } \\
\text { All sectors }\end{array}$ & $\begin{array}{l}1.06^{\star} \\
0.90^{\star} \\
0.82^{\star} \\
0.76^{\star} \\
0.77^{\star} \\
0.97^{\star} \\
0.36^{\star} \\
1.00^{\star} \\
0.52^{\star}\end{array}$ & $\begin{array}{l}(0.21) \\
(0.15) \\
(0.15) \\
(0.04) \\
(0.29) \\
(0.12) \\
(0.37) \\
(0.16)\end{array}$ & $\begin{array}{l}-0.26 \\
-0.20 \\
-0.18 \\
-1.08^{\star} \\
-1.09^{\star} \\
-0.09 \\
-1.01^{\star} \\
-0.62^{\star}\end{array}$ & $\begin{array}{l}(0.21) \\
(0.15) \\
(0.16) \\
(0.23) \\
(0.22) \\
(0.14) \\
(0.10) \\
(0.24)\end{array}$ & $\begin{array}{c}0.31 \\
0.13 \\
2.68 \\
0.37 \\
0.53 \\
0.60 \\
17.78^{\star} \\
0.05\end{array}$ & $\begin{array}{l}0.58 \\
0.65 \\
0.60 \\
0.95 \\
0.72 \\
0.43 \\
0.85 \\
0.63\end{array}$ & $\begin{array}{l}0.47 \\
0.88 \\
0.97 \\
0.77 \\
0.41 \\
0.10 \\
0.69 \\
0.38\end{array}$ \\
\hline
\end{tabular}

Estimation method: OLS, standard errors between brackets, asterisk denotes $5 \%$ significance LM: Breusch-Godfrey Lagrange Multiplier test for first order serial correlation, asterisk denotes $5 \%$ significance

Notice that the short-term and long-term R\&D expenditure elasticities of wages in metal industries are both small, indicating that R\&D expenditure has a modest overall effect on wages. On the other hand, for universities we find a large short-term elasticity and a small long-term elasticity, which means that R\&D expenditure has a strong effect on university wages within one year, but a weak effect on the long run.

The short-term and long-term wage elasticities of the supply of R\&D workers are given in table 7.3, which contains the estimation results of equations (7.3) and (7.4). All estimated short-term elasticities are positive and significant at the $5 \%$ level, except for government institutions. Cointegration of R\&D employment and 
instrumented wages is rejected (Dickey-Fuller tests) in 4 out of 10 sectors, but not at the aggregate level. The estimated adjustment speed coefficients are insignificant in all sectors for which cointegration was rejected and three additional sectors. However, all the adjustment speed coefficients have the plausible negative sign. We do not drop the disequilibrium term from regression equation (7.4), because of the risk of introducing omitted variable bias in the estimation of the short-term elasticity. Possible non-stationarity of the disequilibrium term may be a minor problem, as the weak power of Dickey-Fuller tests often leads to an an incorrect rejection of cointegration. At the aggregate level the adjustment speed coefficient is significant, hence we conclude that there is a long-term equilibrium relationship between supply and wages, although the speed at which wages return to the long-run equilibrium level is difficult to estimate precisely in about half of the sectors. With exception of TNO \& PNP, the error correction mechanism adequately captures the short-term and long-term dynamics as indicated by the low LM-values. The $R^{2}$ ranges from 0.54 to 0.96 , which is satisfactory.

At the aggregate level, the short-term elasticity is 0.96 and the long-term elasticity is 1.20. At the sector level, the short-term elasticities vary between 0.22 and 1.37 , while the long-term elasticities range from 0.48 to 2.04. In 6 out of 10 sectors, the long-term elasticity is larger than the short-term elasticity.

Table 7.3

Wage elasticities of the supply of R\&D workers

\begin{tabular}{|c|c|c|c|c|c|c|c|}
\hline $\begin{array}{l}\text { Sector } \\
\text { Metal industries }\end{array}$ & \multicolumn{2}{|c|}{$\begin{array}{l}\text { short-term } \\
\text { elasticity a }\end{array}$} & \multicolumn{2}{|c|}{$\begin{array}{l}\text { adjustment } \\
\text { speed } \mathrm{Y}\end{array}$} & $\begin{array}{l}\text { LM } \\
\\
2.28 \\
0.05 \\
2.02\end{array}$ & $\begin{array}{l}R^{2} \\
0.63 \\
0.64 \\
0.89\end{array}$ & $\begin{array}{c}\text { long-term } \\
\text { elasticity } \beta \\
0.93\end{array}$ \\
\hline $\begin{array}{l}\text { Metal industries } \\
\text { Chemical industries } \\
\text { Food and beverage industry } \\
\text { Transport, communication } \\
\text { and commercial services } \\
\text { Agriculture and fisheries } \\
\text { Other industries } \\
\text { Universities } \\
\text { Government institutions } \\
\text { TNO \& PNP } \\
\text { All sectors }\end{array}$ & $\begin{array}{l}0.96^{\star} \\
0.89^{\star} \\
0.72^{\star} \\
1.37^{\star} \\
0.22^{\star} \\
1.04^{\star} \\
0.96^{\star}\end{array}$ & $\begin{array}{l}(0.22) \\
(0.14) \\
(0.11) \\
(0.23) \\
(0.45) \\
(0.06) \\
(0.22)\end{array}$ & $\begin{array}{l}-0.39 \\
-0.11 \\
-0.53 \\
-0.81^{\star} \\
-0.07 \\
-0.51^{\star} \\
-0.38^{*}\end{array}$ & $\begin{array}{l}(0.22) \\
(0.20) \\
(0.29) \\
(0.20) \\
(0.11) \\
(0.20) \\
(0.16)\end{array}$ & $\begin{array}{c}1.82 \\
0.12 \\
1.92 \\
0.03 \\
4.60^{\star} \\
12.00^{\star} \\
0.03\end{array}$ & $\begin{array}{l}0.54 \\
0.69 \\
0.70 \\
0.68 \\
0.03 \\
0.96 \\
0.54\end{array}$ & $\begin{array}{l}1.04 \\
1.06 \\
0.90 \\
2.04 \\
1.52 \\
0.87 \\
1.20\end{array}$ \\
\hline
\end{tabular}

Estimation method: OLS, standard errors between brackets, asterisk denotes $5 \%$ significance LM: Breusch-Godfrey Lagrange Multiplier test for first order serial correlation, asterisk denotes $5 \%$ significance

Large short-term and long-term elasticities are found for universities (1.37 and 2.04), hence wages have strong effects on supply. This may reflect the lower wage level (see table 7.1), which causes a higher sensitivity of supply to wages, than in most business enterprise sectors. As a result, even though university wages have a relatively stronger effect on supply in the long run, the effects are high both in the short and the long run compared with other sectors in the economy. A large shortterm elasticity is also found for metal industries (1.11) and TNO \& PNP (1.04), while long-term elasticities larger than 1.00 hold for transport, communication and 
commercial services (1.04), research enterprises (1.06), government institutions (1.52) and universities (2.04). On the other side of the spectrum, a small short-term elasticity is found for government institutions (0.22), while a small long-term elasticity is found for food and beverage $(0.48)$. It should be noted that the results for government institutions are not very reliable, as the $R^{2}$ is only 0.03 and neither of the estimated coefficients are significantly different from zero. In other words, the supply of R\&D workers in government institutions hardly seems to be related to wages.

The instrumental variable approach followed in estimating equations (7.1)-(7.4) is aimed at disentangling demand and supply effects on the labour market for R\&D workers. The R\&D expenditure elasticity of wages tries to capture demand effects, such that the instrumented wages that can be formed based on equation (7.2) can be used to estimate labour supply equation (7.4). However, it may also be interesting to directly estimate the effect of $R \& D$ expenditure on $R \& D$ employment. The resulting $R \& D$ expenditure elasticity of $R \& D$ employment reflects both demand and supply conditions. (Hence the terminology "employment" instead of "supply".) Since the European data that we explore in chapter 8 lack information on wages, we will also estimate R\&D expenditure elasticities of employment for 14 Member States of the European Union. Therefore estimating these elasticities on the Dutch data in this chapter will allow us to compare the Dutch results with the European results. Since $R \& D$ employment and $R \& D$ expenditure are non-stationary variables, the cointegration approach will also be followed, as is clear from equations (7.5) and (7.6).

$$
\begin{gathered}
n_{t}=\theta+\beta x_{t}+\mu_{t} \\
\Delta n_{t}=\alpha \Delta x_{t}+Y\left(n_{t-1}-\hat{\theta}-\hat{\beta} x_{t-1}\right)+\varepsilon_{t}
\end{gathered}
$$

The short-term and long-term R\&D expenditure elasticities of the employment of R\&D workers are given in table 7.4 , which shows the estimation results of equations (7.5) and (7.6). All estimated short-term elasticities are positive and significant at the $5 \%$ level, except for government institutions. Cointegration is rejected (Dickey-Fuller tests) in three sectors, but not at the aggregate level. All adjustment speed coefficients are negative, however they are not significant in 7 out of 10 sectors, including the sectors for which cointegration was rejected. We include the disequilibrium term from regression equation (7.6) in order to avoid omitted variable bias in the estimation of the short-term elasticity. Possible non-stationarity of the disequilibrium term may be a limited problem, as the weak power of Dickey-Fuller tests often leads to an an incorrect rejection of cointegration. At the aggregate level the adjustment speed coefficient is significant, hence we conclude that there is a long-term equilibrium relationship between R\&D employment and R\&D expenditure, although the speed at which wages return to the equilibrium level are difficult to estimate precisely in about half of the sectors. With exception of TNO \& PNP, the error correction mechanism adequately captures the short-term and long-term 
dynamics as indicated by the low LM-values. If we exclude government institutions, the $R^{2}$ ranges from 0.58 to 0.88 , which is generally satisfactory. The model exhibits a poor fit for government institutions, as the $R^{2}$ is only 0.21 and both estimated coefficients are not significantly different from zero.

There are about as many sectors with a long-term elasticity which is smaller than the short-term elasticity, as there are sectors with the reverse pattern. At the sector level, the short-term elasticities vary between 0.17 and 1.19 , while the long-term elasticities range from 0.31 to 0.95 . At the aggregate level, the short-term elasticity is 0.47 and the long-term elasticity is 0.50 . Hence the short-term effect and the longterm effect of R\&D expenditure on R\&D employment are about the same size at this level.

Small short-term elasticities are found for government institutions $(0.17)$ and metal industries (0.44), indicating a modest impact of R\&D expenditure on R\&D employment on the short run. Small long-term elasticities are found for metal industries (0.31), food and beverage (0.34), and chemical industries (0.36). Increased R\&D expenditure may have a small long-term effect on R\&D employment in these sectors. However, it should be mentioned the adjustment speed coefficients are difficult to estimate precisely for these sectors, except for metal industries. For chemical industries for example, the short-term elasticity is 0.56 . Hence increased $R \& D$ expenditure in this sector will lead to a decent increase in R\&D employment in the short-run, while the return to the lower long-run equilibrium level may be very slow, as the estimated adjustment speed coefficient is not significantly different from zero.

Table 7.4

$R \& D$ expenditure elasticities of R\&D employment

\begin{tabular}{lllllll}
\hline Sector & $\begin{array}{l}\text { short-term } \\
\text { elasticity } \alpha\end{array}$ & $\begin{array}{l}\text { adjustment } \\
\text { speed } \gamma\end{array}$ & $L M$ & $R^{2}$ & $\begin{array}{c}\text { long-term } \\
\text { elasticity } \beta\end{array}$ \\
\hline Metal industries & $0.44^{*}(0.11)$ & $-0.83^{*}(0.20)$ & 1.61 & 0.60 & 0.31 \\
Chemical industries & $0.56^{*}(0.15)$ & -0.30 & $(0.20)$ & 0.09 & 0.59 & 0.36 \\
Food and beverage industry & $0.90^{*}(0.09)$ & -0.14 & $(0.11)$ & 0.14 & 0.88 & 0.34 \\
Transport, communication & & & & & & \\
and commercial services & $0.80^{*}(0.19)$ & -0.38 & $(0.24)$ & 1.33 & 0.58 & 0.64 \\
Agriculture and fisheries & $0.73^{*}(0.10)$ & -0.24 & $(0.19)$ & 0.25 & 0.75 & 0.78 \\
Research enterprises & $0.61^{*}(0.10)$ & -0.07 & $(0.13)$ & 0.25 & 0.68 & 0.82 \\
Other industries & $0.55^{*}(0.09)$ & -0.57 & $(0.28)$ & 1.96 & 0.70 & 0.69 \\
Universities & $1.19^{*}(0.22)$ & $-0.89^{*}(0.19)$ & 0.16 & 0.71 & 0.95 \\
Government institutions & $0.17^{*}(0.14)$ & -0.28 & $(0.14)$ & 2.26 & 0.21 & 0.50 \\
TNO \& PNP & $1.07^{*}(0.34)$ & $-0.10^{*}(0.10)$ & $17.22^{*}$ & 0.87 & 0.69 \\
All sectors & $0.47^{*}(0.11)$ & $-0.51^{*}(0.19)$ & 0.07 & 0.57 & 0.50 \\
\end{tabular}

Estimation method: OLS, standard errors between brackets, asterisk denotes 5\% significance LM: Breusch-Godfrey Lagrange Multiplier test for first order serial correlation, asterisk denotes $5 \%$ significance

The largest short-term elasticities are found for universities (0.95) and research enterprises (0.82). As a matter of fact, the R\&D expenditure elasticity of R\&D employment in universities is large both in the short run and in the long run. Hence 
for universities, R\&D expenditure has a large effect on R\&D employment both in the short and the long run. Large R\&D expenditure elasticities of R\&D employment may reflect both demand and supply conditions. On the demand side, a sector may be labour-intensive with respect to R\&D activities. On the supply side, R\&D workers may have a high wage elasticity. Both explanations seem to play a role here: for universities we have already found large wage elasticities of supply (both short-term and long-term) and large short-term R\&D expenditure elasticities of wages.

The results from table 7.2-7.4 are compiled in table 7.5. We may summarize this chapter on the Dutch labour market for R\&D workers as follows.

At the aggregate level, we find cointegrating relationships between wages and R\&D expenditure, between R\&D employment and instrumented wages and between R\&D employment and R\&D expenditure. These relationships allow us to obtain logically consistent estimates of short-term and long-term elasticities of three types: R\&D expenditure elasticities of wages, wage elasticities of the supply of R\&D workers and $R \& D$ expenditure elasticities of R\&D employment. The estimated adjustment speed coefficients in the error correction mechanisms from which the elasticities are estimated are all significant, indicating the empirical relevance of the long-term elasticities. The short-term and long-term R\&D expenditure elasticities of R\&D employment are about the same size: 0.50 and 0.47 . These elasticities reflect both demand and supply conditions, which can be disentangled by the other two types of elasticities. The demand side is reflected by the R\&D expenditure elasticities of wages. The short-term elasticity $(0.52)$ is larger than the long-term elasticity $(0.38)$, indicating that $R \& D$ expenditure has a short-term effect on wages with a smaller long-term effect. The supply side is represented by the wage elasticities of the supply of R\&D workers. Here the short-term elasticity (0.96) is smaller than the longterm elasticity (1.20), implying that wage increases do have an effect in the short run, but the additional long run effect is larger. The following picture of the dynamics of the labour market for R\&D workers therefore emerges from the elasticities (see Figure 7.1). In the short-run, an increase in R\&D expenditure has a strong effect wages, while the supply of R\&D workers is still moderately sensitive to the wage rise. In the long run, the effect of R\&D expenditure on wages dampens, but at the same time the sensitivity of the supply of R\&D workers increases. As a net result, the effect on R\&D employment is about the same size in the short and the long run. The strong short-run demand effect is weakened by the relative insensitivity of supply in the short run, while the moderate long-run demand effect is strengthened by the relative sensitivity of supply in the long run. 
Figure 7.1

Summary of the mechanisms of the labour market for knowledge workers in the Netherlands

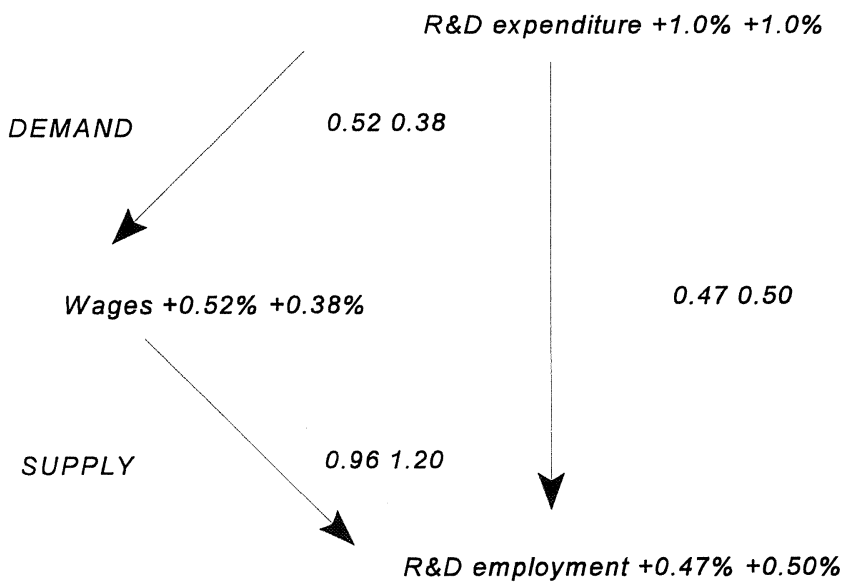

At the sectoral level, the cointegrating relationships are weaker in four sectors: transport, communication and commercial services, agriculture and fisheries, research enterprises and government institutions. For two sectors the modelling results are of the same quality as at the aggregate level, i.e. cointegrating relationships between the three variables and significant short-term elasticities and adjustment speed coefficients in each of the three error correction mechanisms: universities and TNO \& PNP. Universities and TNO \& PNP both have R\&D expenditure elasticities of R\&D employment which are larger in the short run than in the long run. However, there is a difference in the underlying dynamics.

The R\&D expenditure elasticity of wages for universities is stronger in the short run than in the long run, while the opposite is the case for the wage elasticity. In other words, for universities demand effects are stronger in the short run, while supply effects take more time. For TNO \& PNP however, all short-term elasticities are larger than the long-term elasticities. Hence both the demand and supply side exhibit stronger responses in the short run. From table 7.5 it is clear that there is considerable variation in the "term structure of elasticities" across sectors, reflecting different demand and supply conditions.

In the short run (i.e. within one year), a $1.0 \%$ increase in real R\&D spending, leads to a $0.5 \%$ increase in R\&D employment of R\&D workers (in full-time equivalents) and a rise in the real gross wages of R\&D workers of $0.5 \%$. In other words, about half of the increase in R\&D spending actually translates into an increase in knowledge 
activities, as measured by the FTE employment of R\&D workers. The other half ends up as higher rewards for the human capital of R\&D workers.

In the long run, keeping the real R\&D expenditure fixed at the increased level, will lead to a lasting $0.5 \%$ increase of $R \& D$ employment and a permanent $0.4 \%$ increase in wages. Hence the effect of R\&D spending on knowledge activities is fully realized within one year, while the wage effect shows a slight reduction over the following years. This pattern occurs because the short-term wage elasticity of the supply of $R \& D$ workers (in full-time equivalents) is smaller than the long-term elasticity, reflecting the considerable stock of human capital that is embodied in knowledge workers. A $1.0 \%$ increase in wages will increase the supply of R\&D workers (in fulltime equivalents) by $1.0 \%$ in the short run and by $1.2 \%$ in the long run.

However, the results also show considerable variation across different sectors of the economy. Increases in R\&D expenditure have a small effect on R\&D employment in the metal industries, which can largely be ascribed to the demand side. A $1.0 \%$ increase in R\&D spending leads to a mere $0.4 \%$ increase in wages, both in the short run and in the long run. With a short-term wage elasticity of supply of 1.1 and a longterm elasticity of 0.9 , the net effect is a $0.4 \%$ increase in R\&D employment in the short run and a $0.3 \%$ increase in the long run. On the other side of the spectrum, there are also sectors of the Dutch economy where R\&D expenditure leads to strong increases in knowledge activities. A sustained 1.0\% increase in R\&D spending leads to a lasting increase in R\&D employment of $1.0 \%$ for universities and $0.8 \%$ for agriculture and fisheries and research enterprises. For universities, the supply side plays an important role, especially in the long run. For agriculture and fisheries, but also for research enterprises the demand side makes a relatively larger contribution. 


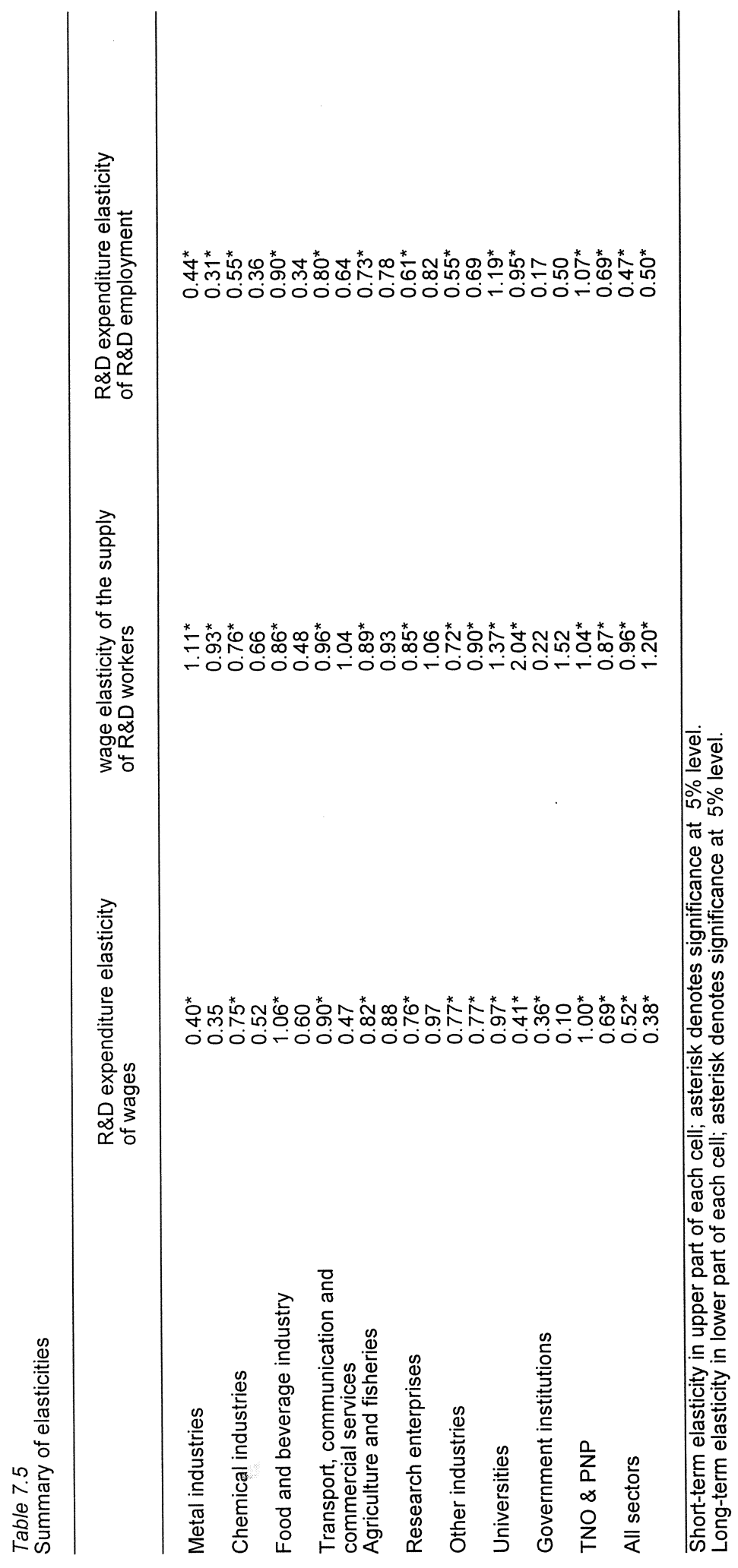


Another way to interpret the various elasticities is as follows. R\&D expenditure in period $t\left(X_{t}\right)$ is made up of labour expenses $\left(L_{t}=N_{t} W_{t}\right)$ and other costs $\left(K_{t}\right)$, such as equipment and buildings. ${ }^{4}$ Additional wage expenditure consists of three components: additional labour at initial wages (first term), additional wages for initial labour stock (second term) and additional wages for additional labour (third term).

$$
\Delta L_{t}=\Delta N_{t} \cdot W_{t-1}+N_{t-1} \cdot \Delta W_{t}+\Delta N_{t} \cdot \Delta W_{t}
$$

The R\&D expenditure elasticities can be approximated as

$$
\begin{gathered}
\theta_{n x}=\frac{\Delta N_{t}}{\Delta X_{t}} \cdot \frac{X_{t-1}}{N_{t-1}} \\
\theta_{w x}=\frac{\Delta W_{t}}{\Delta X_{t}} \cdot \frac{X_{t-1}}{W_{t-1}}
\end{gathered}
$$

which we can rearrange as

$$
\begin{aligned}
& \Delta N_{t}=\theta_{n x} \cdot \frac{N_{t-1}}{X_{t-1}} \cdot \Delta X_{t} \\
& \Delta W_{t}=\theta_{w x} \cdot \frac{W_{t-1}}{X_{t-1}} \cdot \Delta X_{t}
\end{aligned}
$$

Suppose that R\&D expenditure increases by one guilder $\left(\Delta X_{t}=1\right)$, then by substituting (7.10) and (7.11) in (7.7), we can relate additional wage expenditure to the $R \& D$ expenditure elasticities as follows.

$$
\Delta L_{t}=\theta_{n x} \cdot \frac{N_{t-1}}{X_{t-1}} \cdot W_{t-1}+\theta_{w x} \cdot \frac{W_{t-1}}{X_{t-1}} \cdot N_{t-1}+\theta_{n x} \cdot \frac{N_{t-1}}{X_{t-1}} \cdot \theta_{w x} \cdot \frac{W_{t-1}}{X_{t-1}}
$$

4. Notice that we use upper case symbols to indicate levels instead of logarithms. 
The translation of elasticities into level changes can be understood if we look for example at the second term on the right-hand side. For a given R\&D expenditure elasticity of wages, the effect of one additional guilder of R\&D expenditure on the level of wage expenditure (as far as it is caused by additional wages for the initial labour stock) depends positively on the initial wage level, positively on the initial employment level and negatively on the initial level of R\&D expenditure. More generally, the effect of additional R\&D expenditure on the level of wage expenditure positively depends on the initial fraction of $R \& D$ expenditure which is spent on wages $\left(\mathrm{L}_{\mathrm{t}-1} / \mathrm{X}_{\mathrm{t}-1}\right)$.

Equation (7.12) can be used to compute the three effects of one additional guilder of R\&D expenditure on wage expenditure: additional labour at initial wages (first term), additional wages for initial labour stock (second term) and additional wages for additional labour (third term). In practice, the third term is very small. The elasticities can be obtained from table 7.5, while the levels are shown in table $7.1 .^{5}$ If we make the calculation for the short-run effects of R\&D expenditure in all sectors, it turns out that of each additional R\&D guilder, 26 cents are used for additional knowledge activities, while 29 cents disappear in the form of extra wages for the existing stock of knowledge workers. The amount spent on extra wages for extra knowledge activities is negligibly small. The remaining 45 cents are used for equipment and buildings. The calculation for the long-run effects shows that an additional R\&D guilder is split between 28 cents for extra activities, 21 cents for extra wages and 51 cents for extra equipment and buildings. Notice that the short-run and long-run effects on knowledge activities do not differ much, as was the case for the R\&D employment elasticities of R\&D expenditure.

5. In particular, the last column of table 7.1 is very useful as it contains the fraction of initial $R \& D$ expenditure which is spent on wages. 


\section{Appendix 7.A}

Table 7.A.1

Classification of industries

Empirical Analysis (10 sectors)

R\&D Survey (21 sectors)

Metal industries

Chemical industries

Metal industries

Chemicals

Pharmaceuticals

Rubber and synthetic industry

Food and beverage industry

Transportation, communication

Food and beverage industry

and commercial services

Transportation, communication

Agriculture and fisheries

Research enterprises

and commercial services

Other industries

Agriculture and fisheries

Research enterprises

Other industries

Timber and furniture industry

Paper and graphic industry

Textile, clothing and leather

industries

Building materials

Construction and installation

Electricity, gas and water

Universities

Universities

University-affiliated institutions

Government institutions

Government institutions

Semi-government institutions

TNO \& PNP

PNP 


\section{Evidence from European macro time series}

The previous chapter has shown a serious impact of R\&D expenditure on wages of knowledge workers in the Netherlands. To be able to judge the meaning of the elasticities it is interesting to put these Dutch estimates in a European context. At the European level, data on R\&D labour costs are scarce. As a result, estimating wage elasticities is problematic. However, harmonized data on R\&D employment and total R\&D expenditure are available from Eurostat from 1981 to 1995 . Consequently, it is possible to estimate the effect of R\&D spending on the R\&D employment for the Member States of the European Union. The available R\&D data distinguish between three types of R\&D workers: research scientists and engineers (RSEs), technicians and support staff. Since RSEs are the core of the broader group R\&D workers, possessing the largest amount of human capital, we will focus on them. The estimation procedure is similar to chapter 7 . Since we cannot estimate equations (7.1)-(7.4) for other European countries, we have to settle for equations (7.5)-(7.6). This implies that the results in this chapter, $R \& D$ expenditure elasticities of RSE employment, reflect both supply and demand conditions.

The R\&D data are at a relatively high level of aggregation, as only three sectors are distinguished: the business enterprise sector, the government sector and the higher education sector. Employment is expressed in numbers of RSEs in full-time equivalents (FTEs). R\&D expenditure is expressed in national currency, in real terms (base year $=1990$ ). Since we estimate elasticities, conversion into ECUs is not necessary to allow comparison across countries. The quality of the harmonized Eurostat data on RSE employment and R\&D expenditure is somewhat poor in certain cases. In particular, quite a few data are in fact interpolations, which is especially harmful to dynamic modelling exercises, such as cointegration analysis.

Unit root tests (Dickey-Fuller) reject the stationarity of RSE employment and R\&D expenditure in all fourteen EU countries, in all three sectors and also for the aggregate of the three sectors. Taking into account the weak power of Dickey-Fuller tests and the sometimes poor quality of the data, there is evidence of stationarity of the first differences of RSE employment and R\&D expenditure, although it is much stronger in the government and higher education sector than in the business sector or the aggregate of the three sectors.

Cointegration tests (Dickey-Fuller) reveal a much weaker connection between shortterm elasticities and long-term elasticities than in chapter 7, even for the Netherlands. RSE employment has a rather weak tendency to return to the level indicated by the long-run equilibrium relationship with $R \& D$ expenditure. The error correction mechanisms will therefore often show insignificant adjustment speed coefficients. However, estimating short-term elasticities without dropping the disequilibrium term is a logically consistent way of estimating short-term and long-term elasticities. It also reduces the risk of omitted variable bias: variation caused by long-term dynamics is filtered out, allowing for precise tracking of the short-term dynamics 
which generate the short-term elasticity. In addition, by following the same approach as in chapter 7 , we are able to compare the elasticities of chapter 7 and 8 . Anyway, the estimation results in this chapter show that estimating with or without disequilibrium term does not cause large differences in the estimated short-term elasticities. For purposes of interpretation however, this means that long-term elasticities could have weak empirical relevance, as the tendency of RSE employment to move towards its long-term equilibrium level may be slow.

The results at the aggregate level, i.e. all three sectors combined, are shown in table 8.1. All estimated short-term elasticities are positive and significant, except for Belgium and the United Kingdom. For most countries, such as the Netherlands, the adjustment speed coefficient has a negative sign, but it is often not significant. However, if the disequilibrium term is dropped there is little change in the estimated short-term elasticities. For example, for the Netherlands the elasticity changes from 0.82 to 0.78 (with an LM of 1.7 and an $R^{2}$ of 0.28 ) and for France it goes from 0.92 to 0.91 . For countries with an incorrect sign of the adjustment coefficient, there is also little difference if we drop the disequilibrium term. For Austria it changes from 1.11 to 1.05. The same holds for countries with an insignificant short-term elasticity: for Belgium, the elasticity is unchanged $(0.88)$ and for the United Kingdom the elasticity changes from 0.34 to 0.30 . For Belgium the elasticity becomes significant. In general, for the first decimal of the short-term elasticity, the inclusion of the disequilibrium term does not make a difference. For a few countries, there is still some serial correlation left in the error terms, indicated by high LM-values. The advantage of using a similar error correction mechanism for all countries, is the comparability of the elasticities across countries and the avoidance of omitted variable bias which would result from dropping the disequilibrium term. The $R^{2}$ ranges from 0.19 (United Kingdom) to 0.93 (Denmark).

Short-term elasticities larger than 1.00 are found for Austria (1.11) and Germany (1.10). Small short-term elasticities are found for Sweden (0.29) and Italy (0.45), while the elasticities for Belgium (0.88) and the United Kingdom (0.34) are insignificantly different from zero. The short-term elasticity for the Netherlands is 0.82. For the United Kingdom and Belgium, R\&D expenditure does not seem to have a significant impact on RSE employment in the short-run. The short-term elasticity of the Netherlands is more or less average for the European Union.

Long-term elasticities larger than 1.00 are found for Ireland (1.52), the United Kingdom (1.27), the Netherlands (1.11), Germany (1.10) and Finland (1.04). Small long-term elasticities are found for Italy (0.68), Greece (0.80), Portugal (0.81) and Spain (0.82). However, except for Spain and Finland, the adjustment speed coefficient is insignificantly different from zero, implying that the empirical relevance of the long-term elasticities may be rather weak. With this qualification in mind, the long-term elasticities indicate that R\&D expenditure has considerably larger effects on RSE employment in certain Northern European countries than in a number Southern European countries. Due to the lack of wage data, we are not able to estimate the R\&D expenditure elasticity of RSE wages and the wage elasticity of 
RSE supply. In other words, we are not able to distinguish between demand conditions and supply conditions which affect the R\&D expenditure elasticity of RSE employment. From the demand side, a possible explanation for this pattern could be that Spain, Portugal and Greece follow a catching-up policy (European Commission, 1997, p. 314), which could be associated with relatively heavy R\&D expenditure on capital goods. However, a similar policy was in place in Ireland. On the supply side, a shortage of qualified RSEs will translate into low RSE wage elasticities. However, this does not seem to be the case for these countries.

Table 8.1

R\&D expenditure elasticities of RSE employment, all sectors

\begin{tabular}{|c|c|c|c|c|c|c|}
\hline Country & $\begin{array}{l}\text { short-term } \\
\text { elasticity } \beta\end{array}$ & $\begin{array}{l}\text { adjus } \\
\text { speec }\end{array}$ & tment & LM & $\mathrm{R}^{2}$ & $\begin{array}{l}\text { long-term } \\
\text { elasticity } \alpha\end{array}$ \\
\hline $\begin{array}{l}\text { Belgium } \\
\text { Denmark } \\
\text { Germany } \\
\text { Greece } \\
\text { Spain } \\
\text { France } \\
\text { Ireland } \\
\text { Italy } \\
\text { Netherlands } \\
\text { Austria } \\
\text { Portugal } \\
\text { Finland } \\
\text { Sweden } \\
\text { United Kingdom }\end{array}$ & $\begin{array}{ll}0.88 & (0.42) \\
0.93^{\star} & (0.08) \\
1.01^{\star} & (0.42) \\
0.71^{\star} & (0.20) \\
0.50^{*} & (0.15) \\
0.92^{\star} & (0.22) \\
0.73^{\star} & (0.15) \\
0.45^{\star} & (0.18) \\
0.82^{*} & (0.33) \\
1.11^{\star} & (0.23) \\
0.61^{*} & (0.28) \\
0.57^{\star} & (0.08) \\
0.29^{\star} & (0.10) \\
0.34 & (0.21)\end{array}$ & $\begin{array}{l}-0.01 \\
-0.19 \\
-0.09 \\
-0.02 \\
-0.54^{\star} \\
0.02 \\
0.04 \\
-0.32 \\
-0.36 \\
0.10 \\
-0.39 \\
-0.22^{\star} \\
-0.08 \\
-0.06\end{array}$ & $\begin{array}{l}(0.19) \\
(0.17) \\
(0.18) \\
(0.19) \\
(0.23) \\
(0.18) \\
(0.13) \\
(0.29) \\
(0.22) \\
(0.13) \\
(0.35) \\
(0.05) \\
(0.09) \\
(0.08)\end{array}$ & $\begin{array}{l}0.62 \\
3.62 \\
0.77 \\
1.14 \\
2.21 \\
6.29^{\star} \\
2.38 \\
3.48 \\
1.20 \\
5.36^{\star} \\
1.29 \\
2.86 \\
8.33^{\star} \\
5.92^{*}\end{array}$ & $\begin{array}{l}0.28 \\
0.93 \\
0.46 \\
0.55 \\
0.65 \\
0.65 \\
0.67 \\
0.35 \\
0.42 \\
0.68 \\
0.46 \\
0.83 \\
0.41 \\
0.19\end{array}$ & $\begin{array}{l}0.85 \\
0.99 \\
1.10 \\
0.80 \\
0.82 \\
0.98 \\
1.52 \\
0.68 \\
1.11 \\
0.91 \\
0.81 \\
1.04 \\
0.96 \\
1.27\end{array}$ \\
\hline
\end{tabular}

Estimation method: OLS, standard errors between brackets, asterisk denotes $5 \%$ significance LM: Breusch-Godfrey Lagrange Multiplier test for first order serial correlation, asterisk denotes $5 \%$ significance

The results for the business enterprise sector are shown in table 8.2. All estimated short-term elasticities are positive. For Germany, the Netherlands, Portugal and Sweden they are however not significant. Since dropping the disequilibrium terms yields similar elasticities, this is a minor problem, especially for the Netherlands. For Germany the elasticity changes from 0.71 to 0.91 (significant), for the Netherlands from 0.37 to 0.39 (significant), and for Sweden from 0.21 to 0.18 (almost significant). For Portugal the elasticity changes from 0.07 to 1.05 , but it remains insignificant. Hence we conclude that Portugal may have a small short-term elasticity. The adjustment coefficient for the Netherlands is positive, but insignificant. For the other countries, there is approximately an equal number of positive and negative estimated adjustment speed coefficients. However, the only significant coefficients are negative. Estimating without the disequilibrium term does not change the shortterm elasticities very much: for example, for Belgium the change is from 1.64 to 1.62 and for the United Kingdom from 0.42 to 0.45 . The $R^{2}$ ranges from 0.26 (Sweden) to 0.94 (Denmark)

Short-term elasticities larger than 1.00 are found for Belgium (1.64), Austria (1.30) and France (1.05). 
Small short-term elasticities are found for the United Kingdom (0.42), while the elasticities for Germany (0.71), the Netherlands (0.37), Portugal (0.07) and Sweden $(0.21)$ are insignificantly different from zero. This means that R\&D expenditure may have a small impact on RSE employment in the short-run for the business sector in the Netherlands.

Long-term elasticities larger than 1.00 are found for Ireland (1.49), the United Kingdom (1.27), Germany (1.09) and the Netherlands (1.08). Small long-term elasticities are found for Italy (0.64), Greece (0.71), Portugal (0.73) and Spain (0.74). However, except for Portugal, the adjustment speed coefficients are insignificant, which means that the long-term elasticities may have limited empirical relevance. The long-term elasticities nevertheless indicate that R\&D expenditure has considerably larger effects on RSE employment in the business enterprise sector in certain Northern European countries than in a number Southern European countries. This pattern was also evident from the aggregate results (table 8.1) and discussed earlier.

Table 8.2

R\&D expenditure elasticities of RSE employment, business enterprise sector

\begin{tabular}{llccccc}
\hline Country & $\begin{array}{c}\text { short-term } \\
\text { elasticity } \alpha\end{array}$ & $\begin{array}{c}\text { adjustment } \\
\text { speed } y\end{array}$ & LM & $\mathrm{R}^{2}$ & $\begin{array}{c}\text { long-term } \\
\text { elasticity } \beta\end{array}$ \\
\hline Belgium & $1.64^{*}(0.47)$ & 0.02 & $(0.11)$ & 1.89 & 0.52 & 0.81 \\
Denmark & $0.96^{*}(0.07)$ & -0.11 & $(0.18)$ & 2.05 & 0.94 & 0.95 \\
Germany & $0.71(0.33)$ & -0.19 & $(0.18)$ & 0.70 & 0.50 & 1.09 \\
Greece & $0.77^{*}(0.17)$ & 0.03 & $(0.10)$ & $4.91^{\star}$ & 0.67 & 0.71 \\
Spain & $0.83^{*}(0.15)$ & -0.04 & $(0.10)$ & 2.93 & 0.77 & 0.74 \\
France & $1.05^{*}(0.18)$ & -0.02 & $(0.14)$ & $4.41^{*}$ & 0.79 & 0.96 \\
Ireland & $0.74^{*}(0.13)$ & 0.15 & $(0.09)$ & 2.19 & 0.74 & 1.49 \\
Italy & $0.57^{*}(0.13)$ & -0.11 & $(0.23)$ & 2.75 & 0.66 & 0.64 \\
Netherlands & $0.37(0.18)$ & 0.04 & $(0.13)$ & 0.48 & 0.33 & 1.08 \\
Austria & $1.30^{*}(0.39)$ & 0.08 & $(0.11)$ & $7.66^{*}$ & 0.49 & 0.89 \\
Portugal & $0.07(0.85)$ & $-1.29 *$ & $(0.28)$ & 0.83 & 0.65 & 0.73 \\
Finland & $0.70^{*}(0.11)$ & -0.17 & $(0.15)$ & 0.48 & 0.77 & 0.99 \\
Sweden & $0.21(0.10)$ & -0.05 & $(0.11)$ & $10.49^{*}$ & 0.26 & 0.93 \\
United Kingdom & $0.42^{*}(0.16)$ & 0.04 & $(0.07)$ & 0.02 & 0.45 & 1.27 \\
\hline
\end{tabular}

Estimation method: OLS, standard errors between brackets, asterisk denotes $5 \%$ significance LM: Breusch-Godfrey Lagrange Multiplier test for first order serial correlation, asterisk denotes $5 \%$ significance

The results for the government sector are shown in table 8.3. Slightly more than half of the estimated short-term elasticities are significant. All significant estimates are positive. Only Belgium has a negative coefficient. Dropping the disequilibrium term does not yield much improvement: only the German elasticity becomes significant, while changing only marginally, from 0.94 to 0.97 . For the Netherlands, the elasticity changes from 0.32 to -0.24 , however in both cases not significantly different from zero. The adjustment coefficient for the Netherlands is negative and significant, while the $R^{2}$ is 0.82 . There is still some serial correlation indicated by the LMstatistic. Hence we may draw the conclusion that the short-term elasticity for RSEs in the Dutch government sector may be very small. Recall from table 7.3 that the 
estimated short-term elasticity for R\&D workers in Dutch government institutions was also insignificantly different from zero. However, semi-government institutions were found to have a significant short-term elasticity of 1.07. Although the Eurostat data offer less detail by economic sector, they do represent the core group of R\&D workers: the RSEs. Finding smaller R\&D expenditure elasticities of employment for RSEs than for the broader group of R\&D workers may be explained from a supply perspective by the higher stock of human capital that is embodied by RSEs.

Short-term elasticities which are insignificantly different from zero are found for the Netherlands, Belgium, Greece, Ireland and Italy. Hence for these countries R\&D expenditure may lead to a very minor increase in RSE employment in the short run. Large and significant short-term elasticities are found for Portugal (1.93), Spain (1.52), Sweden (1.08), Denmark (1.04) and Austria (1.03).

Small long-term elasticities are found for Italy (0.63), Portugal (0.75), Spain (0.76) and Greece (0.77).

Large long-term elasticities are found for Ireland (1.61), the United Kingdom (1.30), the Netherlands (1.17), Germany (1.16) and Finland (1.13). However, the adjustment speed coefficients are significant only for Ireland, Italy, the Netherlands, Portugal and Finland. Hence for the other countries the long-term elasticities may have modest empirical meaning. The pattern in the long-term elasticities however is comparable with the business enterprise sector: large elasticities for a number of Northern European countries and small elasticities for certain Southern European countries. The striking difference with the business enterprise sector however, lies in the short-term elasticities. Ireland and the Netherlands have large long-term elasticities and at the same time very small short-term elasticities.

Table 8.3

R\&D expenditure elasticities of RSE employment, government sector

\begin{tabular}{|c|c|c|c|c|c|c|}
\hline Country & $\begin{array}{l}\text { short-term } \\
\text { elasticity a }\end{array}$ & $\begin{array}{l}\text { adjus } \\
\text { spee }\end{array}$ & $d_{Y}$ & LM & $\mathrm{R}^{2}$ & $\begin{array}{l}\text { long-term } \\
\text { elasticity } \beta\end{array}$ \\
\hline $\begin{array}{l}\text { Belgium } \\
\text { Denmark } \\
\text { Germany } \\
\text { Greece } \\
\text { Spain } \\
\text { France } \\
\text { Ireland } \\
\text { Italy } \\
\text { Netherlands } \\
\text { Austria } \\
\text { Portugal } \\
\text { Finland } \\
\text { Sweden } \\
\text { United Kingdom }\end{array}$ & $\begin{array}{cc}-0.21 & (0.19) \\
1.04^{\star} & (0.25) \\
0.94 & (0.44) \\
0.35 & (0.23) \\
1.52^{*} & (0.54) \\
0.60^{\star} & (0.20) \\
0.40 & (0.22) \\
0.29 & (0.25) \\
0.32 & (0.60) \\
1.03^{\star} & (0.24) \\
1.93^{*} & (0.65) \\
0.53^{\star} & (0.16) \\
1.08^{*} & (0.39) \\
0.76^{\star} & (0.16)\end{array}$ & $\begin{array}{l}-0.06 \\
-0.21 \\
-0.24 \\
-0.29 \\
0.03 \\
-0.15 \\
-0.31^{\star} \\
-0.47^{\star} \\
-1.45^{\star} \\
0.02 \\
-1.02^{\star} \\
-0.20^{\star} \\
-0.05 \\
-0.10\end{array}$ & $\begin{array}{l}(0.19) \\
(0.29) \\
(0.19) \\
(0.22) \\
(0.18) \\
(0.15) \\
(0.11) \\
(0.17) \\
(0.20) \\
(0.15) \\
(0.38) \\
(0.08) \\
(0.14) \\
(0.14)\end{array}$ & $\begin{array}{l}0.01 \\
0.45 \\
3.57 \\
0.14 \\
4.02^{\star} \\
4.49^{\star} \\
5.13^{\star} \\
1.07 \\
9.45^{\star} \\
5.13^{*} \\
3.62 \\
1.04 \\
4.53^{\star} \\
0.11\end{array}$ & $\begin{array}{l}0.13 \\
0.61 \\
0.35 \\
0.20 \\
0.45 \\
0.55 \\
0.53 \\
0.44 \\
0.82 \\
0.64 \\
0.60 \\
0.53 \\
0.41 \\
0.67\end{array}$ & $\begin{array}{l}0.77 \\
1.01 \\
1.12 \\
0.77 \\
0.76 \\
0.96 \\
1.61 \\
0.63 \\
1.17 \\
0.85 \\
0.75 \\
1.08 \\
1.01 \\
1.30\end{array}$ \\
\hline
\end{tabular}

Estimation method: OLS, standard errors between brackets, asterisk denotes $5 \%$ significance LM: Breusch-Godfrey Lagrange Multiplier test for first order serial correlation, asterisk denotes $5 \%$ significance 
The results for the government sector in the Netherlands show that increased R\&D spending may have negligible effects on RSE employment in the short-run, but considerable effects in the long-run.

The results for the higher education sector are shown in table 8.4. All estimated short-term elasticities are positive. For Ireland, Italy, Finland and Sweden they are however not significant. Dropping the disequilibrium term does not yield significant short-term elasticities either. All estimated adjustment speed coefficients are negative, although rarely significant. Estimating without the disequilibrium term makes a modest difference. For the Netherlands the short-term elasticity changes from 1.01 to 0.93 , with a decrease in the $R^{2}$ from 0.85 to 0.80 . For Germany the elasticity changes from 1.49 to 1.58 and for Belgium from 0.39 to 0.35 .

Short-term elasticities larger than 1.00 (and significant) are found for Germany (1.49), the United Kingdom (1.11) and the Netherlands (1.01). Short-term elasticities which are insignificantly different from zero are found for Ireland, Italy, Finland and Sweden as mentioned earlier.

Large long-term elasticities are found for the United Kingdom (1.38), the Netherlands (1.17) and Germany (1.16). Small long-term elasticities are found for Italy (0.70), Greece (0.82), Portugal (0.85) and Spain (0.87). This pattern is similar to the other sectors and the aggregate results for long-term elasticities.

Table 8.4

R\&D expenditure elasticities of RSE employment, higher education sector

\begin{tabular}{lllllll}
\hline Country & $\begin{array}{c}\text { short-term } \\
\text { elasticity } \alpha\end{array}$ & \multicolumn{2}{c}{$\begin{array}{c}\text { adjustment } \\
\text { speed } Y\end{array}$} & $L M$ & $R^{2}$ & $\begin{array}{c}\text { long-term } \\
\text { elasticity } \beta\end{array}$ \\
\hline Belgium & $0.39^{*}(0.10)$ & -0.15 & $(0.09)$ & 0.10 & 0.58 & 0.89 \\
Denmark & $0.81^{*}(0.11)$ & -0.33 & $(0.20)$ & 1.06 & 0.83 & 1.04 \\
Germany & $1.49^{*}(0.40)$ & -0.17 & $(0.21)$ & 0.46 & 0.60 & 1.16 \\
Greece & $0.72^{*}(0.16)$ & -0.30 & $(0.18)$ & $5.09^{*}$ & 0.68 & 0.82 \\
Spain & $0.33^{*}(0.13)$ & -0.15 & $(0.10)$ & 0.10 & 0.39 & 0.87 \\
France & $0.87^{*}(0.26)$ & -0.39 & $(0.24)$ & 2.05 & 0.57 & 1.06 \\
Ireland & $0.59(0.33)$ & -0.11 & $(0.11)$ & 3.56 & 0.23 & 0.93 \\
Italy & $0.21(0.22)$ & -0.08 & $(0.15)$ & 0.52 & 0.08 & 0.70 \\
Netherlands & $1.01^{*}(0.13)$ & -0.59 & $(0.31)$ & 3.58 & 0.85 & 1.17 \\
Austria & $0.66^{*}(0.09)$ & $-0.53^{*}$ & $(0.18)$ & $9.79^{*}$ & 0.84 & 0.93 \\
Portugal & $0.54^{*}(0.10)$ & $-0.63^{*}$ & $(0.14)$ & $4.98^{*}$ & 0.75 & 0.85 \\
Finland & $0.34(0.22)$ & $-0.25^{*}(0.09)$ & $9.11^{*}$ & 0.43 & 1.13 \\
Sweden & $0.33(0.22)$ & -0.20 & $(0.12)$ & 0.70 & 0.35 & 1.00 \\
United Kingdom & $1.11^{*}(0.38)$ & -0.20 & $(0.14)$ & 2.64 & 0.47 & 1.38 \\
& & & & & & \\
\end{tabular}

Estimation method: OLS, standard errors between brackets, asterisk denotes $5 \%$ significance LM: Breusch-Godfrey Lagrange Multiplier test for first order serial correlation, asterisk denotes $5 \%$ significance

To conclude, if we compare the short-term R\&D expenditure elasticities of RSE employment in the Netherlands with the elasticities of other Member States of the European Union, we see that the elasticity at the aggregate level is more or less average. However, there are considerable differences at the sectoral level. The 
short-term elasticity in the higher education sector is large and significant, while the elasticities for the business enterprise sector and the government sector are insignificant. In other words, increased R\&D expenditure will, in the short run, have more effect on the RSE employment in the higher education sector than in the business enterprise and the government sector. The long-term elasticities of the Netherlands are rather large, but due to the insignificant adjustment speed coefficients, the empirical relevance may be limited. The exception is the government sector, which has an insignificant short-term elasticity and a significant and large adjustment speed to the long-term equilibrium. Hence R\&D expenditure will, in the long run, have a large impact on RSE employment in the government sector, while the long-term elasticities for the business enterprise sector and the higher education sector may be high, but it is difficult to give a reliable quantification.

The absence of a short-term effect of R\&D expenditure on RSE employment may reflect both demand and supply conditions. On the demand side, the additional R\&D funds may be spent on non-RSE R\&D workers, i.e. technicians and support staff. Another demand side explanation is that the extra R\&D funds could be spent on physical capital, such as laboratory equipment, computers, buildings etc., instead of labour. On the supply side, small wage elasticities of RSE supply may cause the increase in R\&D expenditure to lead to higher wages for RSEs and/or other R\&D workers. In this case a rise in, for example, government expenditure on R\&D may lead to a crowding out of RSEs from other sectors in the national economy. However, any or all of these demand and supply mechanisms may be at work at the same time.

If we compare the results on RSEs in the Netherlands, with the results from chapter 7 on the broader group of R\&D workers, we see that for the Dutch economy as a whole, increases in R\&D expenditure tend to focus on the RSEs. While the shortterm and long-term R\&D expenditure elasticities of R\&D employment are both 0.5 , the short-term and long-term R\&D elasticities of RSE employment are larger: 0.8 and 1.1. Compared with other European countries the short-term elasticity for RSE employment is more or less average, but the long-term elasticity is relatively large. The long-term elasticities are about the same size (1.1 to 1.2) in the three broad sectors distinguished in the Eurostat data. The short-term elasticities however show striking differences. The short-term elasticities of RSE employment in the business enterprise sector $(0.4)$ and the government sector (0.3) are insignificant, while the short-term elasticity in the higher education sector is large (1.0) and significant. In other words, only in the higher education system do increases in RSE employment take place rapidly. It takes more time for the business enterprise sector and the government sector. In the long run, the effects are similar, as we already mentioned. For the broader group of R\&D workers, employment in government institutions also does not seem to be very responsive to R\&D expenditure with an insignificant shortterm elasticity (0.2) and a long-term elasticity of 0.4 . In the various business sectors distinguished in the $R \& D$ survey there are large differences in $R \& D$ expenditure elasticities of R\&D employment: the short-term elasticities vary between 0.4 and 0.9 , while the long-term elasticities range from 0.3 to 0.8 . As was the case for RSEs in 
the higher education sector, the employment of R\&D workers in universities is highly responsive to R\&D expenditure with a short-term elasticity of 1.2 and a long-term elasticity of 1.0 . 


\section{Conclusion}

The effectiveness of R\&D policies is bounded by the low elasticity of the supply of knowledge workers, both in the short run and the long run. As a consequence, increased R\&D expenditure will partially be absorbed by increased competition among firms for the available workers, therefore leading to wage increases which reduce the effect of $R \& D$ expenditure on R\&D activities. Goolsbee (1998) provided evidence that increases in R\&D expenditure in the US lead to wage rises rather than increased knowledge activities. This report investigated evidence for such mechanisms in the Netherlands.

The most valuable source of information on R\&D workers in the Netherlands is the R\&D Survey of Statistics Netherlands. At the aggregate level, we find cointegrating relationships between wages and R\&D expenditure, between R\&D employment and instrumented wages and between R\&D employment and R\&D expenditure. These relationships allow us to obtain logically consistent estimates of short-term and longterm elasticities of three types: R\&D expenditure elasticities of wages, wage elasticities of the supply of R\&D workers and R\&D expenditure elasticities of R\&D employment. The estimated adjustment speed coefficients in the error correction mechanisms from which the elasticities are estimated are all significant, indicating the empirical relevance of the long-term elasticities. The short-term and long-term R\&D expenditure elasticities of R\&D employment are about the same size: 0.50 and 0.47 . These elasticities reflect both demand and supply conditions, which can be disentangled by the other two types of elasticities. The demand side is reflected by the $R \& D$ expenditure elasticities of wages. The short-term elasticity $(0.52)$ is larger than the long-term elasticity (0.38), indicating that R\&D expenditure has a short-term effect on wages with a smaller long-term effect. The supply side is represented by the wage elasticities of the supply of R\&D workers. Here the short-term elasticity $(0.96)$ is smaller than the long-term elasticity (1.20), implying that a permanent wage increase does have an effect in the short run, but the additional long run effect is larger. The following picture of the dynamics of the labour market for R\&D workers therefore emerges from the elasticities. In the short-run, an increase in R\&D expenditure has a strong effect wages, while the supply of R\&D workers is still moderately sensitive to the wage rise. In the long run, the effect of R\&D expenditure on wages dampens, but at the same time the sensitivity of the supply of R\&D workers increases. As a net result, the effect on R\&D employment is about the same size in the short and the long run. The strong short-run demand effect is weakened by the relative insensitivity of supply in the short run, while the moderate long-run demand effect is strengthened by the relative sensitivity of supply in the long run. In other words, when R\&D expenditure is increased, the demand side of the labour market compensates for the short-run inflexibility of the supply side by strong wage increases in the short run and weaker responses in the long run.

The economic implications of the estimated elasticities are as follows. In the short run (i.e. within one year), a $1.0 \%$ increase in real R\&D spending, leads to a $0.5 \%$ 
increase in R\&D employment of R\&D workers (in full-time equivalents) and a rise in the real gross wages of R\&D workers of $0.5 \%$. In other words, about half of the increase in R\&D spending actually translates into an increase in knowledge activities, as measured by the FTE employment of R\&D workers. The other half ends up as higher rewards for the human capital of R\&D workers. In the long run, keeping the real R\&D expenditure fixed at the increased level, will lead to a lasting $0.5 \%$ increase of R\&D employment and a permanent $0.4 \%$ increase in wages. Hence the effect of R\&D spending on knowledge activities is fully realized within one year, while the wage effect shows a slight reduction over the following years. This pattern occurs because the short-term wage elasticity of the supply of R\&D workers (in fulltime equivalents) is smaller than the long-term elasticity, reflecting the considerable stock of human capital that is embodied in knowledge workers. A $1.0 \%$ increase in wages will increase the supply of R\&D workers (in full-time equivalents) by $1.0 \%$ in the short run and by $1.2 \%$ in the long run.

Additional evidence from Eurostat on the core group of R\&D workers, the research scientists and engineers, shows that for the Dutch economy as a whole, increases in $R \& D$ expenditure tend to focus on this group. While the short-term and long-term $R \& D$ expenditure elasticities of R\&D employment are both 0.5 , the short-term and long-term R\&D elasticities of RSE employment are larger: 0.8 and 1.1. Compared with other European countries the short-term elasticity for RSE employment is more or less average, but the long-term elasticity is relatively large.

The speed at which RSE employment reacts to R\&D expenditure varies across the three broad sectors distinguished in the Eurostat data. The long-term elasticities are similar between the sectors, but the higher education sector has a large short-term elasticity, while the business enterprise sector and government sector have insignificant short-term elasticities. The increases in RSEs takes more time in the latter two sectors, while there is a strong effect within one year in the higher education sector. For the broader group of R\&D workers, employment in government institutions also does not seem to be very responsive to R\&D expenditure. In the various business sectors distinguished in the $R \& D$ survey there are large differences in R\&D expenditure elasticities of R\&D employment. As was the case for RSEs in the higher education sector, the employment of R\&D workers in universities is highly responsive to $R \& D$ expenditure.

The more detailed sector data in the R\&D Survey of Statistics Netherlands also show interesting differences between sectors, resulting from considerable variation in the "term structure of elasticities" across sectors, reflecting different demand and supply conditions. A sustained $1.0 \%$ increase in R\&D spending leads to a lasting increase in R\&D employment of $1.0 \%$ for universities and $0.8 \%$ for agriculture and fisheries and research enterprises. For universities, the supply side plays an important role, especially in the long run. For agriculture and fisheries, but also for research enterprises the demand side makes a relatively larger contribution. On the other side of the spectrum, a $1.0 \%$ increase in $R \& D$ expenditure in the metal industries only leads to a $0.4 \%$ increase in R\&D employment in the short run and a 
$0.3 \%$ increase in the long run. The small effect of R\&D expenditure on R\&D employment in metal industries can largely be ascribed to the demand side.

The elasticities estimated from the R\&D Survey of Statistics Netherlands indicate that in the short run, of each additional R\&D guilder spent in the Netherlands, 26 cents are used for additional knowledge activities, 45 cents are spent on extra equipment and buildings, while 29 cents disappear in the form of extra wages for the existing stock of knowledge workers. In the long run, still 21 cents disappear via wage rises, while the effect on knowledge activities does not improve much as 28 cents are spent on it out of every additional R\&D guilder. The remaining 51 cents are used for equipment and buildings. 


\section{References}

Becker, G.S., 1962, Investment in human capital: A theoretical analysis, Journal of Political Economy 70, no. 5, pt. 2, p. 9-49.

Borghans, L., de Grip, A. \& Smits, W., 1995, Beroepsmobiliteit technisch opgeleiden, OSA D-1, Den Haag.

Borghans, L., Delmee, J. \& de Grip, A., 1997, Ontwikkelingen in het beroepsdomein van hoger technisch opgeleiden, In: Kennis en economie 1997, Centraal Bureau voor de Statistiek, Voorburg/Heerlen.

CBS, 1998, Kennis en economie 1998, Centraal Bureau voor de Statistiek, Voorburg/Heerlen.

David, P.A.\& Hall, B.H., 2000, Heart of Darkness: Modeling Public-Private Funding Interactions Inside the R\&D Black Box, NBER Working Paper No. W7538. Revised version (March 24, 1999) of paper presented to the American Economic Association Meetings session "In honor of Edwin Mansfield", New York, January 5, 1999.

Engle, R.F. \& Granger, C.W.J., 1987, Co-integration and error correction: representation, estimation and testing, Econometrica 55, p. 251-276.

European Commission, 1997, Second European Report on S\&T Indicators, Office for Official Publications of the European Communities, Luxembourg.

Gilbert, C.L., 1996, Professor Hendry's econometric methodology, Oxford Bulletin of Economics and Statistics, 48, p.283-307.

Goolsbee, A., 1998, Does government R\&D policy mainly benefit scientists and engineers?, American Economic Review, Vol. 88 No. 2, p. 298-302.

Hamermesh, D.S., 1999, The art of labormetrics, NBER Working Paper No. W6927.

Hoffmann, E., 1998, Collecting Statistics on Imbalances in the Demand for Labour, Bureau of Statistics, International Labour Office.

Kennan, J., 1988, An econometric analysis of fluctuations in aggregate labor supply and demand, Econometrica 56, p. 317-333.

Kimmel, J. \& Kniesner, T.J., 1998, New evidence on labor supply: Employment versus hours elasticities by sex and marital status, Journal of Monetary Economics 42, p. 289-301.

KIvl, 1998, Ingenieur en salaris 1998, The Hague.

Kniesner, T.J. \& Goldsmith, A.H., 1987, A survey of alternative models of the aggregate U.S. labor market, Journal of Economic Literature 25, p. 1241-1280. 
Lehfeldt, R.A., 1915, Review of H.L. Moore: Economic Cycles: Their Law and Cause, Economic Journal 25, p. 409-411.

Leontief, W.W., 1953, Domestic Production and Foreign Trade: The American Capital Position Reexamined, Proceedings of the American Philosophical Society 93 , p. 332-349.

Leontief, W.W., 1956, Factor Proportions and the Structure of American trade: Further Theoretical and Empirical Analysis, Review of Economics and Statistics 38, p. 386-407.

Mincer, J., 1958, Investment in human capital and personal income distribution, Journal of Political Economy 66, p. 281-302.

Moore, H.L., 1994, Economic Cycles - Their Law and Cause, Macmillian, New York.

Morgan, M.S., 1990, The History of Econometric Ideas, Cambridge University Press, Cambridge (UK).

Nelson, C.R. \& Plosser, C.I., 1982, Trends and Random Walks in Macroeconomic Time Series: Some Evidence and Implications, Journal of Monetary Economics 10, p. 139-162.

Rogerson, R. \& Rupert, P., 1993, On testing the intertemporal substitution theory of labor supply, Journal of Economic Dynamics and Control 17, p. 37-50.

Romer, P.M., 1986, Increasing Returns and Long-Run Growth, Journal of Political Economy 94, p. 1002-1037.

Romer, P.M., 1990, Endogenous technological change, Journal of Political Economy 98, S71-S102.

Schultz, T.W., 1961, Investment in human capital, American Economic Review 51, p. 1-17.

Wright, P.G., 1915, Review of H.L. Moore: Economic Cycles, Journal of the American Statistical Association 19, p. 103-108. 